\title{
Comparative Shear Tests of Bolt Rods Under Static and Dynamic Loading
}

https://doi.org/10.2478/sgem-2019-0038

received November 20, 2019; accepted January 29, 2020.

\begin{abstract}
This article presents the methodology and results of single shear tests of bolt rods under dynamic impact loading generated by means of a drop hammer. Comparative analysis was also performed for bolt rod load capacity, stress and shear work under static and dynamic (impact) loading. The developed method of single shear testing of bolt rods under impact loading makes it possible to obtain repeatable test results concerning maximum bolt rod shearing force, shear stress and shear work values.

Comparative shear tests of four types of bolt rods under static and impact loading showed that the APB-type bolt rods made of AP770 steel, which was characterised by having the highest strength, exhibited the greatest shear work. AM22type bolt rods exhibited a very similar work value. Though the AM22-type bolt rods made of A500sh steel demonstrated lower strength than the APB-type bolts, as well as a smaller diameter and cross section, they dissipated the impact energy better thanks to their higher plasticity. This could indicate the direction of optimisation for bolt rods in order to increase their impact strength.

Mathematical relationships were also formulated for selected tests, describing the real single shear courses $\mathrm{Fd}=\mathrm{f}($ t) of bolts under impact loading. The obtained relationships could be applied in the load assessment process of bolt rods intended for use under roof caving, tremor and rock burst conditions.
\end{abstract}

Keywords: rock bolt; laboratory bolt test; static and dynamic single shear test; shear work.

\section{Introduction}

Maintaining the stability of mine workings under the conditions of increased static loading and dynamic impact loading constitutes a significant problem in underground mines. This particularly concerns ultra-deep

*Corresponding author: Andrzej Pytlik, Central Mining Institute, Katowice, Poland, E-mail: apytlik@gig.eu;ja.pytlik mines with depths under $1000 \mathrm{~m}$, where excavations are established by means of roof bolting. This can be observed in the cases of working stability loss in the Polish copper mines, occurring as a result of rock bursts (Dubiński \& Konopko, 2000; Fuławka et al., 2018) induced by mining activities. Seismic activity analysis showed (Burtan et al., 2017) that the rock bursts were primarily caused by high-energy rock mass tremors with an energy of $A_{\mathrm{s}} \geq 10^{5}$ J. High-energy tremors occur primarily as a result of the presence of tremor-generating rock formations above the mined deposit, as well as due to the influence of faulting and also the depth and already moved-out area. The maximum mining depth of those mines has been already $1300 \mathrm{~m}$, the copper ore deposits are extracted via various forms of room-and-pillar mining, while the most numerous occurrences of rock bursts have been observed with tremors with energy of $A_{\mathrm{s}}=10^{6}-10^{7} \mathrm{~J}$ (Gogolewska \& Kaźmierczak, 2014; Pytel et al., 2019).

In the case of the utilisation of roof bolting under the conditions of a discontinuous rock mass, that is, fractured (Skrzypkowski et al., 2017) or blocky (Cała et al., 2001), bolt rod shear strength plays a significant role. An example diagram of a gallery working in a blocky rock mass secured against the falling of a block with a weight $W$ via roof bolting is presented in Fig. 1 .

A three-dimensional numerical analysis of a rock burst that occurred in the Kiirunavaara Mine (LKAB, Sweden) (Sjöberg et al., 2011) shows that a shear along pre-existing geological formations (with block structures) was the probable cause of the seismic event that resulted in a fatal accident in the mine in 2008. Therefore, a significant problem exists regarding the selection of rock bolt supports for tremor and rock burst conditions that would dissipate the energy of the rocks moving into the working. Thus, as well as static mechanical properties, the dynamic properties of bolts should also be determined.

Major problems connected to maintaining mine working stability also occur in ultra-deep gold mines (extraction at a depth of $4000 \mathrm{~m}$ ) in the Republic of South Africa (Sengani, 2018). Increasing work safety is possible only via the utilisation of rock mass destressing, correct support design and support element technical parameter 
testing over the course of numerous tests conducted under laboratory conditions (static and dynamic tests) and underground (static tests).

World-widely, test methodologies and standardisations concerning the mechanical elements and steel from which bolt rods are formed can be found, for example, in countries such as: Australia, Austria, Canada, Germany, Poland, the Republic of South Africa, Sweden, the United Kingdom and the USA. In Europe, for example, the general requirements for steel and other materials are defined in the European standard EN 1537 (2000), which has been translated into many languages (e.g., British standard BS EN 1537:2000). General requirements for mechanical elements and steel have also been defined in the Republic of South Africa: SABS 1408 (2002) and SANS 920 (2005).

In Poland, detailed requirements for bolts under static loading are defined in standard PN-G-15091 (1998), whereas their tests are defined in standard PN-G-15092 (1999). Static strength tests are conducted for bolt rods (tensile, bending, shear and torsional strength; impact testing), washers, lagging, grouting agents and grout cartridges. Bolt rod load capacity is tested under laboratory or underground conditions (in situ) (Niedbalski et al., 2013). Bolt rod shear strength tests are based on a single shear test of only the rod itself (not grouted into a tube or cylinder).

Example standardisations that include test methodologies of bolts under static loading can be found in, for example, German (DIN 21521 Teil 1 1990; DIN 21521 Teil 2 1993), British (BS 7861-1 2007) and American (ASTM F432-13 2013) standards. In the case of the German and British standards, single shear tests of bolt rods are also conducted, but the bolts are grouted into tubes or cylinder segments.

Static double shear tests of bolts and numerical modelling results (Aziz et al., 2003; Li et al., 2016; Mirzaghorbanali et al., 2017), the purpose of which is to inspect the influence of various parameters on the behaviour of the bolt during shear tests, can also be found in literature.

Shear strength tests of bolts under dynamic loading are currently not standardised. Scientific work conducted at the University of Wollongong (Australia) concerning the test methodology of bolts under static and dynamic shear loading (Aziz et al., 2008; Gilbert et al., 2015; Li et al., 2014; Yang et al., 2018; Jalalifar, 2006) can be found in literature. The bolt tests are conducted via double shear testing of bolts or single shear testing. For double shear testing (Craig \& Aziz, 2010; Rasekh et al., 2017; Jalalifar et al., 2005), the tests utilise three concrete blocks, whereas

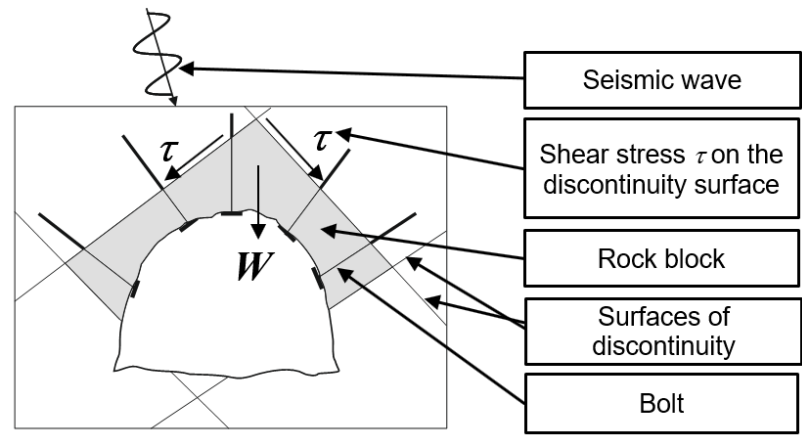

Figure 1: Diagram of a gallery working secured against the falling of a block with a weight $W$ via roof bolting (Cała et al., 2001).

the single shear tests (Aziz et al., 2017; Aziz et al., 2018; Li et al., 2019) utilise cylinders filled with concrete, consisting of two sections. The shearing cylinders are fabricated in two sections, each containing $1.8 \mathrm{~m}$ of a concrete anchor cylinder, providing a centrally located shearing plane. The double shear tests of bolts under dynamic loading are based on the method of exerting loads by means of a drop hammer (pile-driving hammer) with a mass of $600 \mathrm{~kg}$.

However, the double and single shear tests of bolts installed in concrete or rock blocks do not yield satisfactory results for bolt manufacturers, who expect a method enabling the evaluation of the shear strength of a bolt rod under impact loading and the strength comparison of various materials and types of bolts. The influence of grout, rock or concrete strength during shear tests is significant enough to make the evaluation of the strength of the bolt rod itself difficult (Jalalifar et al., 2005). Another reason for the difficulty in assessing bolt rod shear strength are local instances of spalling (occurring at the point where the guillotine is applied) of the grout, cement or concrete, which result in the formation of complex stress, which is also significantly influenced by bolt rod bending and tension.

The American standard ASTM D7401-08 (2008) concerning dynamic drop tests is one example of a standard that defines the test methodology of a bolt under dynamic loading. The bolt rod is grouted into a thick-walled steel pipe and not into a concrete or rock block. According to this standard, the tensile impact load exerted on the bolt is based on the drop hammer method. Tests of bolts under dynamic loading are conducted by world-renowned laboratories in Australia, Canada, South Africa and Sweden. One of the best-known laboratories in the world is CANMET-MMSL in Canada (CANMET Mining and Mineral Sciences Laboratories), which has been conducting tests under both static and dynamic loading for many years (Labrie et al., 2008; Plouffe et al., 2008). 
Bolt tests under impact loading by means of the drop hammer method are also carried out at the Central Mining Institute in Poland (Nierobisz et al., 2001; Prusek et al., 2016; Pytlik et al., 2016). Initially, the tests were conducted using an impact mass ranging from $4000 \mathrm{~kg}$ to $20,000 \mathrm{~kg}$ at maximum impact velocities of up to $v=3 \mathrm{~m} / \mathrm{s}$. Due to the fact that the PPV (Peak Particle Velocity) values within the near wave field determined on the basis of 120 rock bursts that had occurred in Polish hard coal mines did not exceed $v=1 \mathrm{~m} / \mathrm{s}$ (Dubiński \& Mutke, 1996; Mutke, 2007; Mutke et al., 2016), the bolts were mostly tested using an impact mass of 20,000 kg and an impact velocity of 0.4-1.2 $\mathrm{m} / \mathrm{s}$.

Other than bolts, the test facility is also used to conduct impact tests of powered support and single prop support hydraulic legs (Pytlik, 2015a; Pytlik, 2015b; Prusek et al., 2016; Pytlik, 2018), friction props, ropes, chains and mine grids. Tests of shotcrete and membranes are also performed by means of box of rocks tests, using a drop mass of up to $4000 \mathrm{~kg}$.

The current technical capabilities of the Central Mining Institute drop hammer facility for mine support element testing allow the tests of structural elements, that is, hydraulic legs, chains, ropes and cable bolts, with a maximum impact energy $E_{\mathrm{p}} \approx 500 \mathrm{~kJ}(m=20,000 \mathrm{~kg}, h$ $=2.5 \mathrm{~m}$ ) to be conducted. As for bolts tested based on the American standard ASTM D7401-08 (2008), the current capabilities allow the testing of bolts with a maximum length of $3 \mathrm{~m}$ by means of an impact mass of $5600 \mathrm{~kg}$ dropped from a height of approximately $3 \mathrm{~m}$. This makes it possible to load the bolt with an impact energy $E \approx 165$ $\mathrm{kJ}$ and impact velocity $v \approx 7.67 \mathrm{~m} / \mathrm{s}$.

These test facility parameters allow to simulate impact loads at broad ranges of impact energy and velocity, which are observed in situ. For example, during tests that were conducted in iron ore mines (Shirzadegan et al., 2016a; Shirzadegan et al., 2016b) belonging to LKAB (Sweden), the measured maximum PPV was 7.5 $\mathrm{m} / \mathrm{s}$. Rock burst simulations performed under gold mine conditions (Haile \& Le Bron, 2001; Milev et al., 2001; Milev 7 Spottiswoode, 2005) in the Republic of South Africa also revealed high PPV values, reaching up to $3.3 \mathrm{~m} / \mathrm{s}$. PPV measurement results (at depths of up to approximately $1000 \mathrm{~m}$ ) in Polish hard coal mines showed that maximum vertical PPV component values reached up to $1 \mathrm{~m} / \mathrm{s}$, while the horizontal component values reached up to $1.56 \mathrm{~m} / \mathrm{s}$, and incidentally to $1.97 \mathrm{~m} / \mathrm{s}$ (Kidybiński et al., 2009; Mutke, 2007). The corner frequencies varied between 8.3-31.1 $\mathrm{Hz}$. The corner frequencies are the frequencies that carry most of the seismic energy and momentum. For the $85 \%$ of rock bursts, the corner frequency does not exceed $23 \mathrm{~Hz}$ (Mutke et al., 2016). In Polish copper mines (for seismic events of energy greater than $10^{5} \mathrm{~J}$ monitored in the near-field wave), the velocity may occur in the range of $0.027-0.095 \mathrm{~m} / \mathrm{s}$. The highest values of velocity have been measured by frequency of several $\mathrm{Hz}$ (Pytel, 2003). The maximum value of the PPV equals to $0.197 \mathrm{~m} / \mathrm{s}$ measured at a hypocentral distance of $64 \mathrm{~m}$ from seismic event of energy $A_{\mathrm{s}}=5.5 \cdot 10^{5} \mathrm{~J}$, but this value did not cause a rock burst (Nierobisz, 2004). Values of rock vibration velocity generated by seismic waves for Polish copper mines have not been sufficiently recognized and more researches are needed.

The impact velocity $v$ of the free-falling mass in the GIG test facility, is not the same as the PPV on the surface of the mine workings (Pytlik et al., 2016). The methodology assumes that such correlation exists and applies only to the first impulse of the load and not to the wave motion. This is because in addition to the wave motion, there is another rock mass movement, which is a common cause of the destruction of mine workings (Drzewiecki, 2002). This movement is associated with the motion of large volumes of rock mass initiated by the creation or propagation of discontinuities. The direction of this movement is consistent with the area with the most degrees of freedom.

This article presents a methodology for the single shear testing of bolt rods and the results of bolt tests that enable the determination of bolt dynamic shear strength under impact loading exerted by means of a drop hammer. A maximum impact velocity of $v=$ $2 \mathrm{~m} / \mathrm{s}$ was adopted for the tests, as an implication of Polish experiments conducted during PPV in situ measurements. A comparison was also performed for the work dissipated by the bolt rods under static and impact loading, from which two types, AM18 and AM22, were formed via thermal hardening (heating - stamping quenching), whereas the other two types, APP and APB, were formed via hot rolling, while the steel was smelted in electric arc furnaces, cast using continuous casting machines and finally subjected to slow cooling. Thus, the APP and APB bolt rods exhibit more uniform structures across their entire cross sections compared to the AM18 and AM22 bolts, which are surface-hardened, while their cores exhibit higher plasticity.

The obtained test results allowed to formulate mathematical relationships for the bolt shearing force under impact loading as a function of time of the duration of the impulse of the force. 


\section{Methodology for Static Loading}

The test methodology for single shear testing of bolts under static loading was developed based on a Polish standard (PN-G-15092:1999). The shearing of a bolt rod with an outer diameter $D$ is based on the gradual material integrity deterioration initiated by the excessive pressure of the guillotine, exerted against the rod on both sides of the sheared cross section. The $250 \mathrm{~mm}$-long bolt rod sample is placed in a hole with a maximum diameter of $D+2 \mathrm{~mm}$ located in the die of the bolt rod shearing device, presented in the form of a diagram in Fig. 2.

Bolt shear testing is based on loading a bolt rod sample with an increasing shearing force until the rod is shorn. The shearing force is exerted on the bolt rod by a punch (guillotine) with a minimum outer diameter of $3 \times D$ and a maximum load rate of up to $5 \mathrm{kN} / \mathrm{s}$. Sliding the (cylinder-shaped) punch in the die, which has a very small clearance, up to $136 \mathrm{~mm}$, made possible by the fitting tolerance between the die and the punch, allows the bending stresses in the shorn bolt rod sample to be minimised.

Bolt shear tests under static loading were conducted using a universal testing machine equipped with a strain gauge force sensor (accuracy class 0.5) and a potentiometric displacement sensor (accuracy class 0.1). The measuring sensors were connected to an MGCplustype measuring amplifier (accuracy class 0.03) coupled with a computer. The measurement data is recorded on the computer with a sampling frequency $f_{\mathrm{s}}=10 \mathrm{~Hz}$. Based on the measurement data, a graph of the static shearing force $F_{s}$ as a function of bolt rod shear displacement $L$ is generated, and the maximum shearing force $F_{\text {smax }}$ measured during the test is defined.

Bolt rod shear strength $t_{s}$ (Niezgodziński M.E. \& Niezgodziński T., 1996) under static loading is calculated using the following formula:

$$
\tau_{s}=\frac{F_{\text {smax }}}{A_{e}} 10^{3}, \mathrm{MPa}
$$

where: $F_{\text {smax }}$ - maximum force during the shear test under static loading, kN; $A_{\mathrm{e}}$ - effective bolt rod cross section area, $\mathrm{mm}^{2}$.

In the case of a bolt rod formed from a round plain bar with a diameter $D$, the bar cross section is calculated using the following formula (2):

$$
A_{e}=A=\frac{\pi \cdot D^{2}}{4}, \mathrm{~mm}^{2}
$$

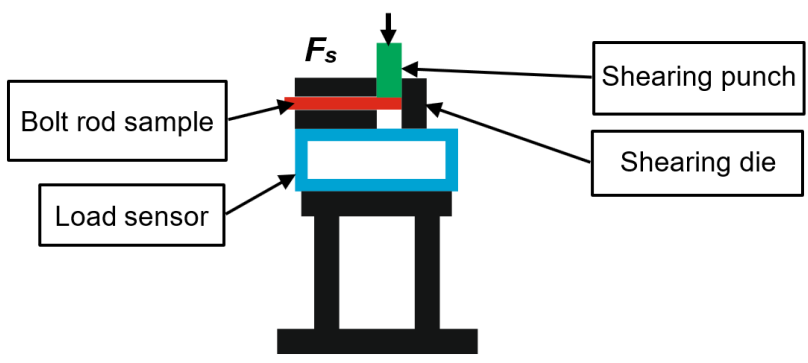

Figure 2: Test facility diagram for bolt rod single shear testing under static loading

whereas, for a rod formed from a ribbed bar, the effective cross section area $A_{\mathrm{e}}$ and effective diameter $D_{\mathrm{e}}$ of the bar are calculated using the following formulas ( $\mathrm{PN}-\mathrm{H}-$ 93215:1982):

$$
\begin{gathered}
A_{e}=\frac{m_{r}}{\rho \cdot l_{r}} 10^{6}=127.4 \frac{m_{r}}{l_{r}}, \mathrm{~mm}^{2} \\
D_{e}=12.74 \sqrt{\frac{m_{r}}{l_{r}}}, \mathrm{~mm}
\end{gathered}
$$

where: $D$ - diameter of the rod formed from a round plain bar, $\mathrm{mm} ; D_{\mathrm{e}}$ - effective diameter of the rod, $\mathrm{mm} ; l_{\mathrm{r}}$ - length of the rod sample, $\mathrm{m} ; m_{\mathrm{r}}$ - mass of the rod sample, $\mathrm{kg} ; r$ density of steel $\left(r=7850 \mathrm{~kg} / \mathrm{m}^{3}\right)$

Based on the chart of the course $F_{\mathrm{s}}=\mathrm{f}(L)$ (Fig. 3), the bolt rod shear work $W_{s}$ under static loading is calculated as well.

\section{Methodology for Dynamic Loading}

The objective of the developed single shear testing methodology of bolt rods under impact loading is to conduct relatively simple and repeatable tests, whose results could be used by bolt rod manufacturers, rock bolt support designers and for the purposes of product certification. The methodology also allows to compare the shear impact strengths of various types of bolt rods. The primary goal of the test is to investigate whether the bolt can be safely utilised in underground mines prone to tremors and rock burst hazards.

The tests are conducted in the testing facility presented in Fig. 4. The drop mass (ram) $m=2429 \mathrm{~kg}$ used during the tests simulates the impact load exerted on a bolt rod with varying impact velocity $v$.

The same shearing device is used for bolt rod shear tests under impact loading as for static tests. 


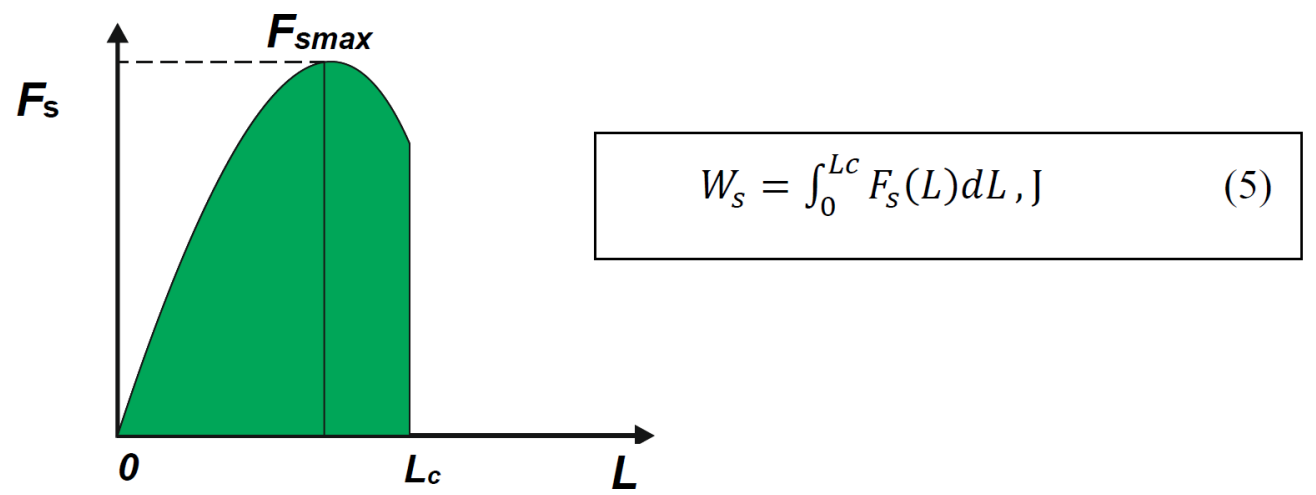

Figure 3: Typical shape of the course $F_{s}=\mathrm{f}(L)$ as well as the area under the curve corresponding to the bolt rod shear work $W_{s}$ under static loading. Where: $L_{c}$ - Displacement until the point of rod shearing, $\mathrm{mm}$.

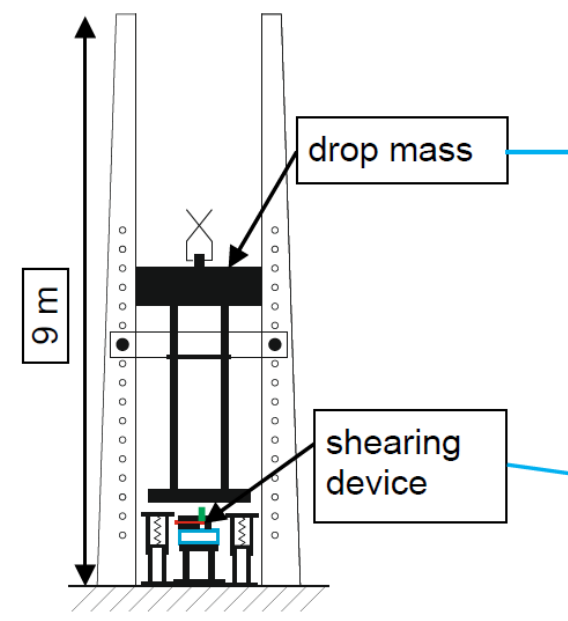

(a)

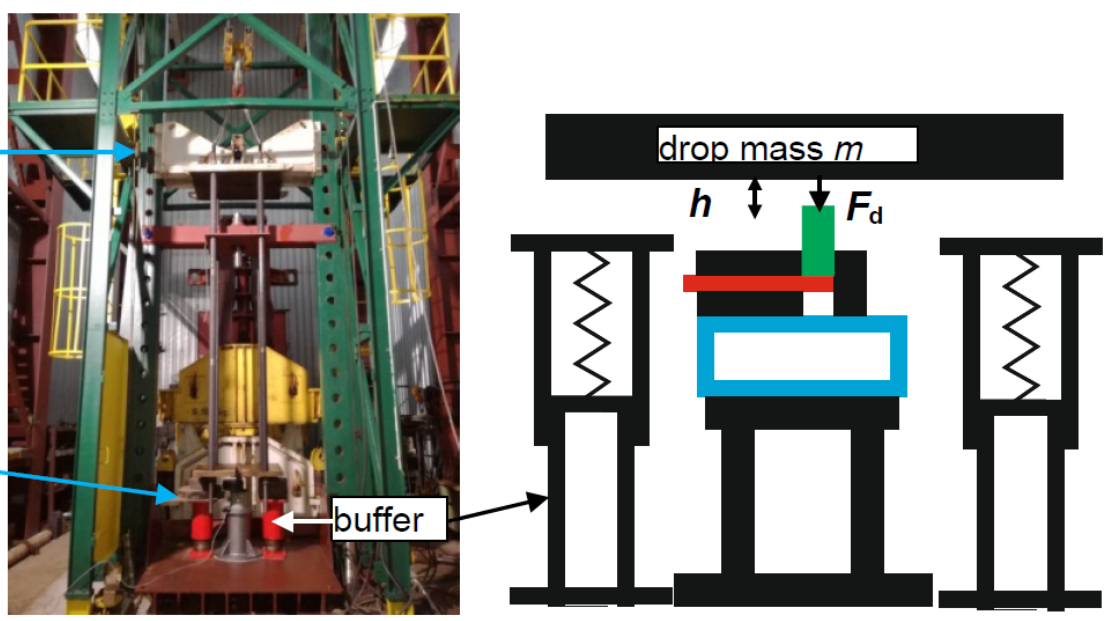

(b)

(c)

Figure 4: The test facility during single shear impact testing of bolt rods by means of a $2429 \mathrm{~kg}$ mass: (a) diagram; (b) view; (c) loading diagram during test.

The single shear test of a bolt under impact loading is based on the free fall of the mass $m=2429 \mathrm{~kg}$ from various heights $h$ directly onto the impact that shears the bolt rod. Each rod is tested until it is completely shorn - via single or multiple impacts of the mass. After the rod is shorn, the ram is intercepted by two buffers (equipped with springs and a liquid elastomer) that secure the test facility from damage.

The bolt impact velocity $v$ during the test is calculated using the following formula (6):

$$
v=\sqrt{2 g h}, \mathrm{~m} / \mathrm{s}
$$

where: $h$ - impact mass height of fall, $\mathrm{m}$; $g$ - gravitational constant, $9.81 \mathrm{~m} / \mathrm{s}^{2}$.
During the test of the bolt under shear impact loading, the bolt dynamic resistance force $F_{\mathrm{d}}$ is registered with a sampling frequency $f_{\mathrm{s}}=19.2 \mathrm{kHz}$. The maximum value $F_{\text {dmax }}$ of the bolt dynamic resistance force $F_{\mathrm{d}}$ at a given impact velocity $v$ is also determined during the test.

Bolt rod shear impact strength $t_{\mathrm{d}}$ is calculated using the following formula (7):

$$
\tau_{d}=\frac{F_{d \max }}{A_{e}} 10^{3}, \mathrm{MPa}
$$

where: $F_{\mathrm{dmax}}-$ maximum force during the shear test under impact loading, $\mathrm{kN}$.

Based on the chart of the course $F_{\mathrm{d}}=\mathrm{f}(t)$ (Fig. 5), the value of the impulse $J$ of the force (Halliday et al., 2007) is calculated using the following formula (8). 


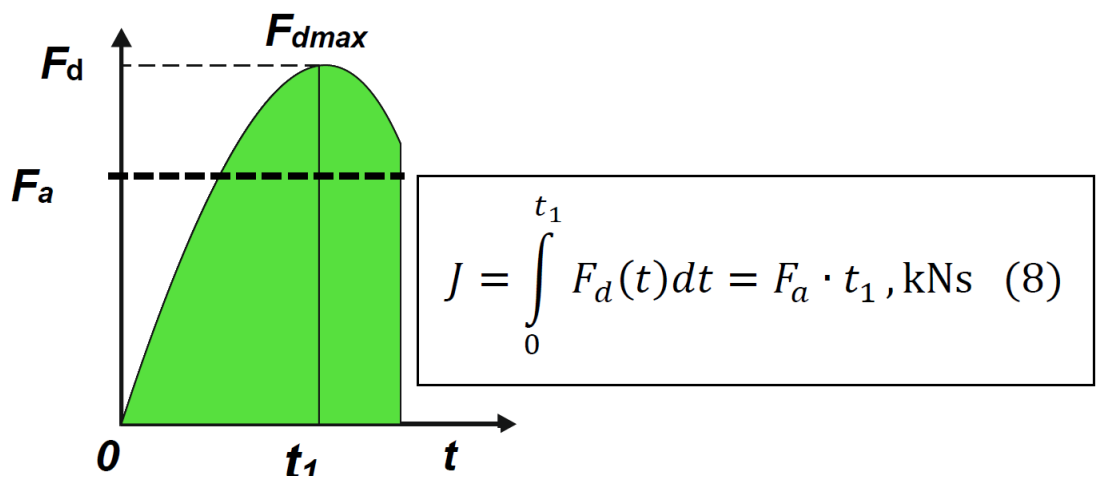

Figure 5: Typical shape of the course $F_{d}=\mathrm{f}(t)$ as well as the area under the curve corresponding to the impulse $J$ of the force during bolt rod shearing. Where: $t_{1}$ - time until the point of bolt rod shearing, $\mathrm{s} ; F_{a}-$ average force during the test, $\mathrm{kN}$.

Table 1: Basic rod dimensions and mechanical properties of steel.

\begin{tabular}{|c|c|c|c|c|c|}
\hline Bolt type & Grade of steel & $\begin{array}{l}\text { Effective bolt rod diameter } \\
D_{e}, \mathrm{~mm}\end{array}$ & Effective area $A_{e}, \mathrm{~mm}^{2}$ & $\begin{array}{l}\text { Ultimate tensile strength } \\
R_{\mathrm{m}}, \mathrm{MPa}\end{array}$ & $\begin{array}{l}\text { Elongation at } \\
\text { rupture } A_{5}, \% \\
\end{array}$ \\
\hline AM18 & A500S & 17.6 & 243.3 & $721.5 \pm 16.8$ & 18 \\
\hline AM22 & A500sh & 21.6 & 366.4 & $762.3 \pm 4.3$ & 23 \\
\hline APP & AP600V & 19.7 & 304.8 & $681.3 \pm 2.9$ & 24 \\
\hline APB & AP770 & 22.1 & 383.6 & $830.4 \pm 7.3$ & 19 \\
\hline
\end{tabular}

The average force $F_{\mathrm{a}}$ is calculated using the following formula:

$$
F_{a}=\frac{J}{t_{1}}, \mathrm{kN}
$$

Bolt rod shear work $W_{\mathrm{d}}$ value under dynamic loading is calculated using the following formula:

$$
W_{d}=F_{a} \cdot L_{c}, \mathrm{~kJ}
$$

where $L_{\mathrm{c}}$ - displacement until the point of bolt rod shearing under static loading, $\mathrm{mm}$. The $L_{\mathrm{c}}$ value is determined during a bolt rod shear test at static load (Figure 3). Due to the significant difficulties in measuring the displacement located in the test facility axis (due to a lack of space to mount a sensor in the facility axis as well as major sensitivity to impact and vibration of the existing sensors on the market), the $L_{\mathrm{c}}$ value from the static test was adopted for calculations in the formula (10).

\section{Test Results Under Static Loading}

Four types of bolts with varied mechanical properties and rods formed from different grades of steel were subjected to testing.
Two types of bolt rods:

I. AM18 - A500S steel - steel intended for concrete reinforcement,

II. AM22 - A500sh steel - steel intended for rock bolt production,

are manufactured via thermal hardening: heating stamping - quenching.

The other two types of bolt rods:

III. APP - AP600V steel - steel intended for rock bolt production,

IV. APB - AP770 steel - steel intended for rock bolt production,

are manufactured as hot-rolled bars, whereas the steel is smelted in electric arc furnaces and cast using continuous casting machines as $120 \times 120 \mathrm{~mm}$ squares. Rods III and IV exhibit more uniform structures across their entire cross sections compared to rods I and II, which are surfacehardened and whose cores retain plasticity.

The basic dimensions of the rods and the mechanical properties of the steel used to produce the bolt rods are presented in Table 1 . The unit elongation $A_{5}$ value is given based on mill certificates (inspection certificates 3.1 in accordance with standard BS EN 10204:2004) of the steel used to produce the bolt rods. Bolt rod ultimate tensile strength $R_{\mathrm{m}}$ under static loading was determined based 


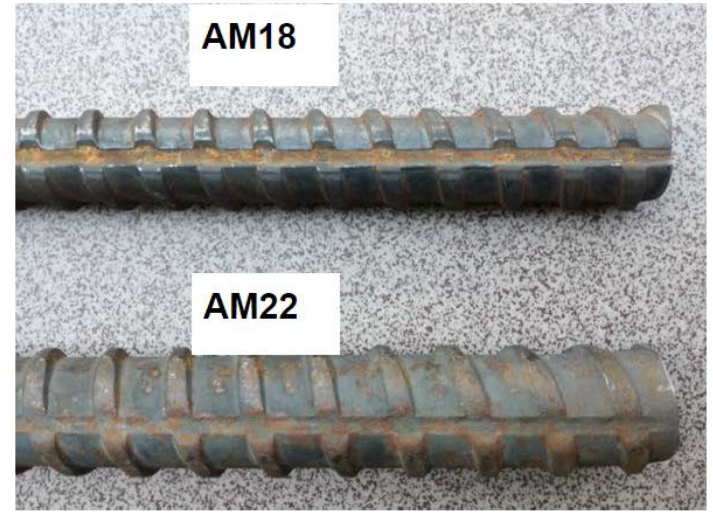

(a)

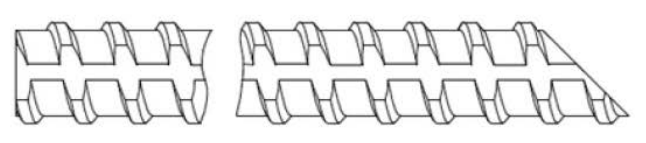

(b)

Figure 6: AM18 and AM22-type bolts: (a) and rod thread profile and cross section diagrams (b).

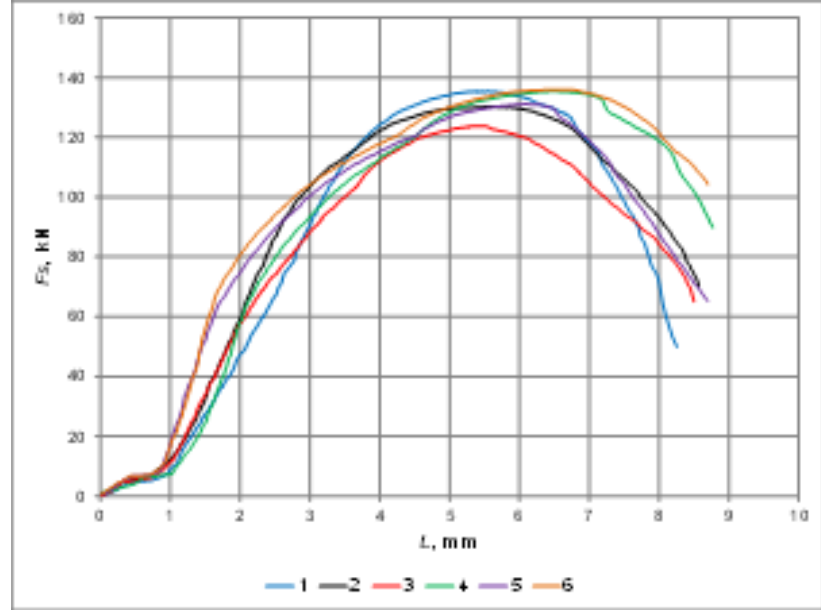

(a)

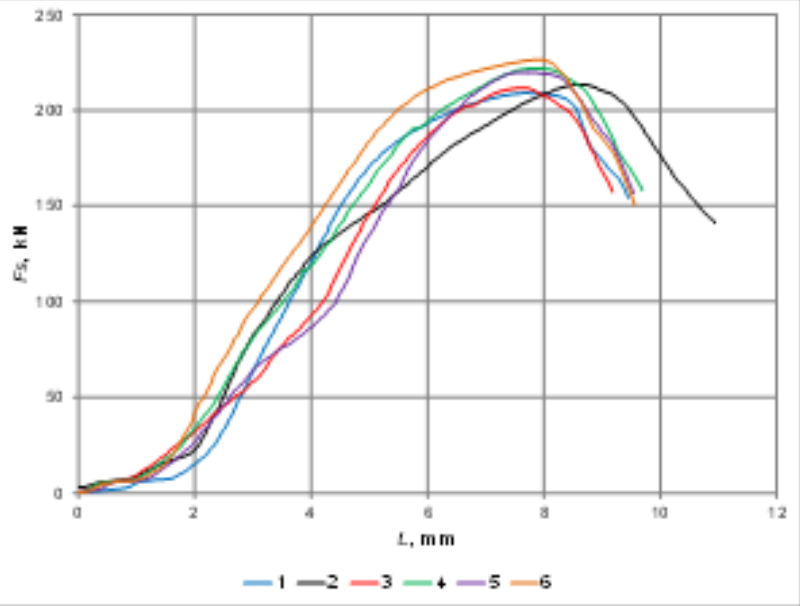

(b)

Figure 7: Load $F_{\mathrm{s}}$ curves as functions of shear displacement $L$ of bolt rods: (a) AM18; (b) AM22.

Table 2: Mechanical properties of AM18 and AM22 bolt rods under static shear loading.

\begin{tabular}{lllll}
\hline Bolt type & Maximum force $F_{\text {smax }}, \mathrm{kN}$ & Shear strength $t_{\mathrm{s}}, \mathrm{MPa}$ & Shear displacement $L_{\mathrm{c}}, \mathrm{mm}$ & Work $W_{\mathrm{s}}, \mathrm{kJ}$ \\
\hline AM18 & $131.9 \pm 4.7$ & $542.3 \pm 19.3$ & $8.6 \pm 0.2$ & $0.775 \pm 0.061$ \\
AM22 & $217.1 \pm 6.7$ & $592.5 \pm 18.4$ & $9.7 \pm 0.6$ & $1.221 \pm 0.131$ \\
\hline
\end{tabular}

on tests of samples extracted from $2 \mathrm{~m}$ long rods. Then, further samples were extracted from the same rods, which were subjected to single shear tests under static and dynamic loading.

A500S and A500sh steel designations were obtained from the catalogue of the bar manufacturer (ArcelorMittal Kryvyi Rih 2016) and from mill certificates. AP600V and AP770 steel designations were obtained from the catalogue of the bar manufacturer (Minova Arnall, 2018) and from mill certificates.

\subsection{AM18 And AM22-Type Grouted Bolt Rods}

AM18-type bolt rods are produced as bars with trapezoidal threads along the entire rod. Fig. 6 presents a view of the bolts, as well as the thread profile and cross section diagrams of the rods.

A result compilation of the single shear tests of AM18 and AM22-type bolt rods under static loading is presented in Table 2, whereas the load $F_{\mathrm{s}}$ curves as functions of shear displacement $L$ are presented in Fig. 7 . 


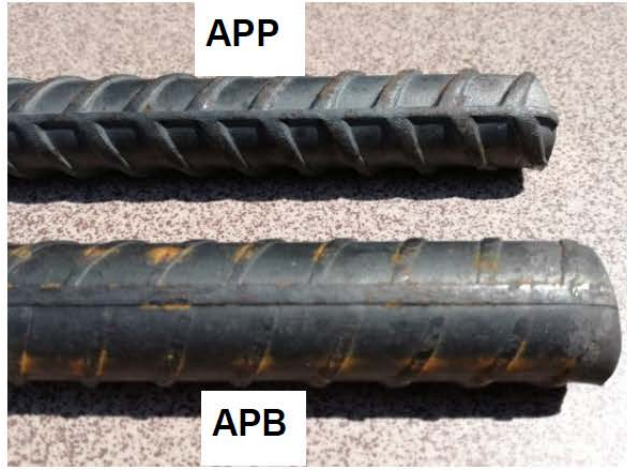

(a)
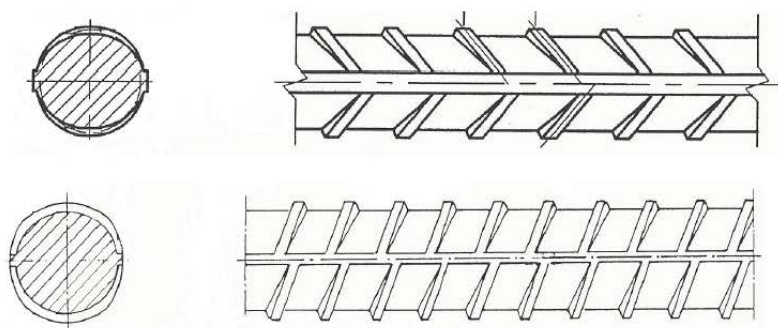

(b)

Figure 8: APP and APB-type bolt rods (a) and cross section diagrams (b).

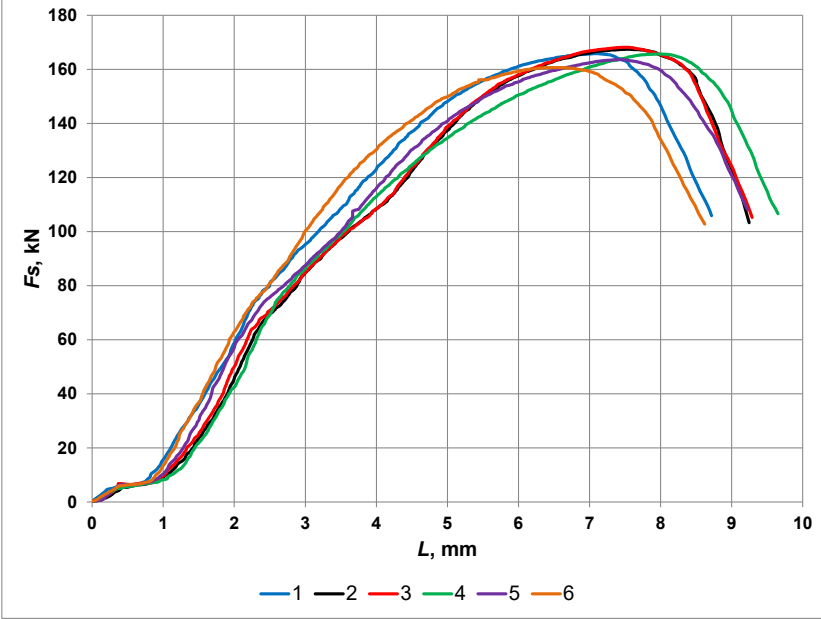

(a)

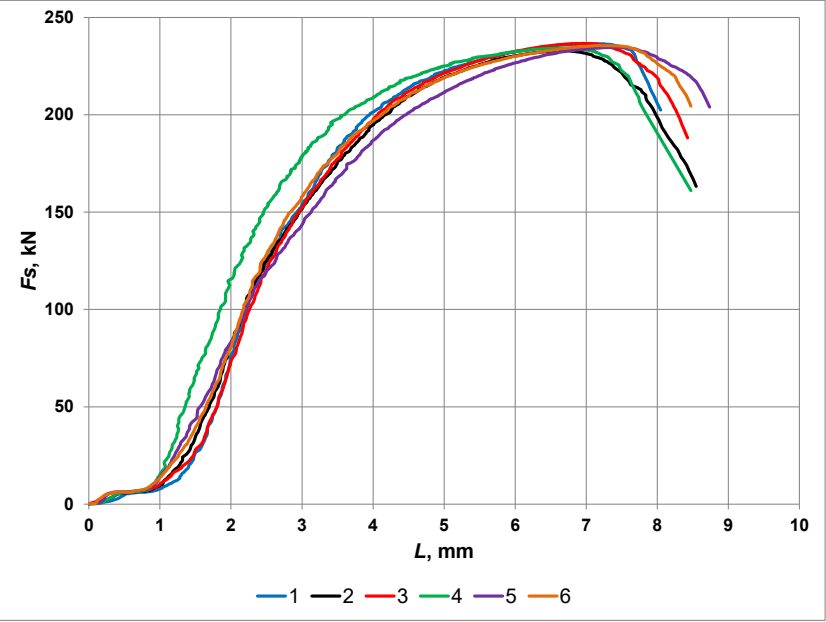

(b)

Figure 9: Load $F_{s}$ curves as functions of shear displacement $L$ of bolt rods: (a) APP; (b) APB.

Table 3: Mechanical properties of APP and APB bolt rods under static shear loading.

\begin{tabular}{lllll}
\hline Bolt type & Maximum force $\boldsymbol{F}_{\mathrm{smax}}, \mathrm{kN}$ & Shear strength $\mathrm{t}_{\mathrm{s}}, \mathbf{M P a}$ & Shear displacement $L_{\mathrm{c}}, \mathrm{mm}$ & Work $W_{\mathrm{s}}, \mathrm{kJ}$ \\
\hline APP & $165.2 \pm 2.7$ & $541.9 \pm 9.0$ & $9.1 \pm 0.4$ & $0.971 \pm 0.036$ \\
APB & $235.1 \pm 1.4$ & $612.8 \pm 3.7$ & $8.5 \pm 0.2$ & $1.340 \pm 0.053$ \\
\hline
\end{tabular}

\subsection{APP And APB-Type Grouted Bolt Rods}

APP and APB-type bolt rods are made of reinforcing steel bars, whose pictures and cross section diagrams are presented in Fig. 8.

A result compilation of the single shear tests of APP and APB-type bolt rods under static loading is presented in Table 3, whereas the load $F_{\mathrm{s}}$ curves as functions of shear displacement $L$ are presented in Fig. 9 .

\section{Test Results Under Impact Loading}

During the bench testing of AM18, AM22, APP and APBtype bolt rods, a total of 88 single shear tests under impact loading by means of a drop hammer were conducted. This made it possible to determine the mechanical properties of bolt rods under impact loading and present them in the form of tables and graphs. It was also possible to formulate mathematical relationships for the bolt rod 


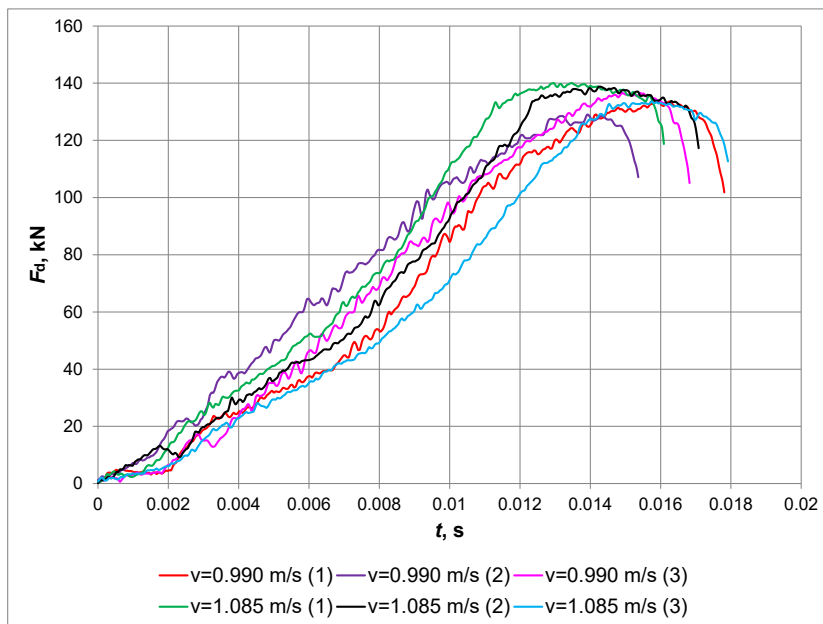

(a)

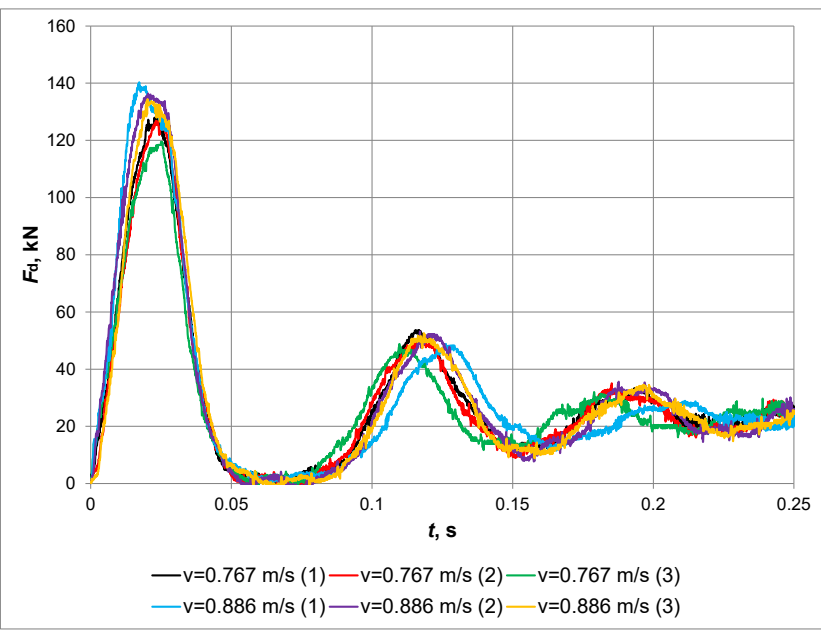

(b)

Figure 10: AM18 bolt rod load $F_{\mathrm{d}}$ curves as functions of time $t$ : (a) the rod was shorn.; (b) the rod was not shorn.

Table 4: Mechanical properties of AM18 and AM22 bolt rods during single shearing under impact loading.

\begin{tabular}{llll}
\hline Bolt type & $\begin{array}{l}\text { Maximum force } \\
\boldsymbol{F}_{\mathrm{dmax}}, \mathbf{k N}\end{array}$ & $\begin{array}{l}\text { Shear strength } \boldsymbol{t}_{\mathrm{d}}, \\
\mathrm{MPa}\end{array}$ & Work $\boldsymbol{W}_{\mathrm{d}}, \mathbf{k J}$ \\
\hline AM18 & $135.3 \pm 4.0$ & $556.0 \pm 16.6$ & $0.630 \pm 0.032$ \\
$\mathrm{AM} 22$ & $225.5 \pm 7.0$ & $615.6 \pm 19.1$ & $1.203 \pm 0.064$ \\
\hline
\end{tabular}

Table 5: Mechanical properties of APP and APB bolt rods during single shearing under impact loading.

\begin{tabular}{llll}
\hline Bolt type & $\begin{array}{l}\text { Maximum force } \\
\boldsymbol{F}_{\mathrm{dmax}}, \mathbf{k N}\end{array}$ & $\begin{array}{l}\text { Shear strength } \\
\mathbf{t}_{\mathrm{d}}, \mathbf{M P a}\end{array}$ & Work $\boldsymbol{W}_{\mathrm{d}}, \mathbf{k J}$ \\
\hline APP & $174.2 \pm 2.5$ & $571.6 \pm 8.3$ & $0.945 \pm 0.033$ \\
APB & $252.0 \pm 3.6$ & $656.9 \pm 9.5$ & $1.269 \pm 0.062$ \\
\hline
\end{tabular}

shearing force under impact loading as a function of the duration of the impulse of the force, which could become useful in the future for modelling rock bolt support loads and for the correct selection of bolts to the geological and mining conditions found in mine workings.

\subsection{AM18 And AM22-Type Grouted Bolt Rods}

A result compilation of the single shear tests of AM18 and AM22 bolt rods under impact loading where rod shearing occurred is presented in Table 4.

Example load $F_{\mathrm{d}}$ curves as functions of time $t$ during AM18-type bolt rod tests where rod shearing occurred are presented in Fig. 10a. During the tests, the minimum impact velocity $v$ of the mass $m=2429 \mathrm{~kg}$ that resulted in the shearing of the bolt rod was $0.990 \mathrm{~m} / \mathrm{s}$. Example load $F_{\mathrm{d}}$ curves as functions of time $t$ during AM18-type bolt rod tests at impact velocities $v=0.767 \mathrm{~m} / \mathrm{s}$ and $v=0.886$ $\mathrm{m} / \mathrm{s}$ that did not result in the shearing of the bolt rod are presented in Fig. 10b.

Example load $F_{\mathrm{d}}$ curves as functions of time $t$ during AM22-type bolt rod tests where rod shearing occurred are presented in Fig. 11a. During the tests, the minimum impact velocity $v$ of the mass $m=2429 \mathrm{~kg}$ that resulted in the shearing of the bolt rod was $1.253 \mathrm{~m} / \mathrm{s}$. Example load $F_{\mathrm{d}}$ curves as functions of time $t$ during AM22-type bolt rod tests at impact velocity $v=1.172 \mathrm{~m} / \mathrm{s}$ that did not result in the shearing of the bolt rod are presented in Fig. 11b.

\subsection{APP And APB-Type Grouted Bolt Rods}

A result compilation of the single shear tests of APP and APB bolt rods under impact loading where rod shearing occurred is presented in Table 5.

Example load $F_{\mathrm{d}}$ curves as functions of time $t$ during APP-type bolt rod tests are presented in Fig. 12a. During the tests, the minimum impact velocity $v$ of the mass $m=$ $2429 \mathrm{~kg}$ that resulted in the shearing of the bolt rod was $1.085 \mathrm{~m} / \mathrm{s}$. Example load $F_{\mathrm{d}}$ curves as functions of time $t$ during APP-type bolt rod tests at impact velocity $v=0.990$ $\mathrm{m} / \mathrm{s}$ that did not result in the shearing of the bolt rod are presented in Fig. 12b.

Example load $F_{\mathrm{d}}$ curves as functions of time $t$ during APB-type bolt rod tests where rod shearing occurred are presented in Fig. 13a. During the tests, the minimum impact velocity $v$ of the mass $m=2429 \mathrm{~kg}$ that resulted in 


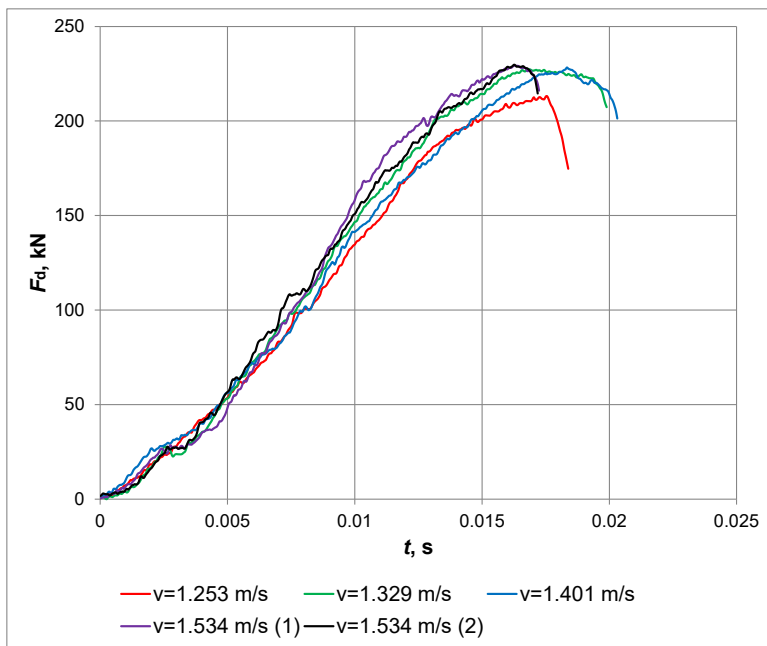

(a)

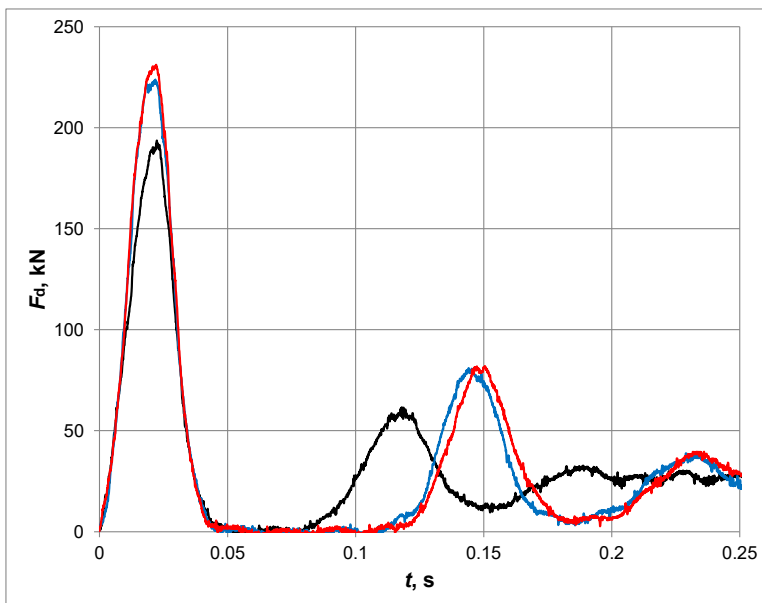

$-v=1.172 \mathrm{~m} / \mathrm{s}(1)-v=1.172 \mathrm{~m} / \mathrm{s}(2) \quad-v=1.172 \mathrm{~m} / \mathrm{s}(3)$

(b)

Figure 11: AM22 bolt rod load $F_{d}$ curves as functions of time $t$ : (a) the rod was shorn.; (b) the rod was not shorn.

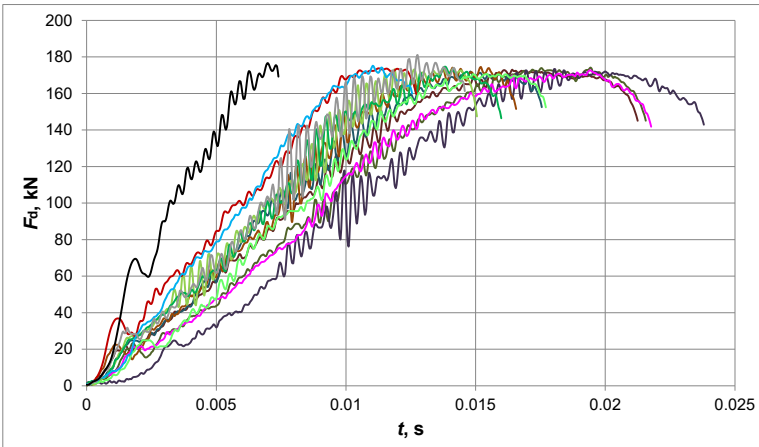

$-v=1.085 \mathrm{~m} / \mathrm{s}(1)-v=1.085 \mathrm{~m} / \mathrm{s}(2)-v=1.085 \mathrm{~m} / \mathrm{s}(3)-v=1.172 \mathrm{~m} / \mathrm{s}(1)$ $-v=1.172 \mathrm{~m} / \mathrm{s}(2)-v=1.172 \mathrm{~m} / \mathrm{s}(3)-v=1.213 \mathrm{~m} / \mathrm{s}(1)-v=1.213 \mathrm{~m} / \mathrm{s}(2)$ $-v=1.213 \mathrm{~m} / \mathrm{s}(3)-v=1.401 \mathrm{~m} / \mathrm{s}(1)-v=1.401 \mathrm{~m} / \mathrm{s}(2)-v=1.401 \mathrm{~m} / \mathrm{s}(3)$ $-v=1.981 \mathrm{~m} / \mathrm{s}$

(a)

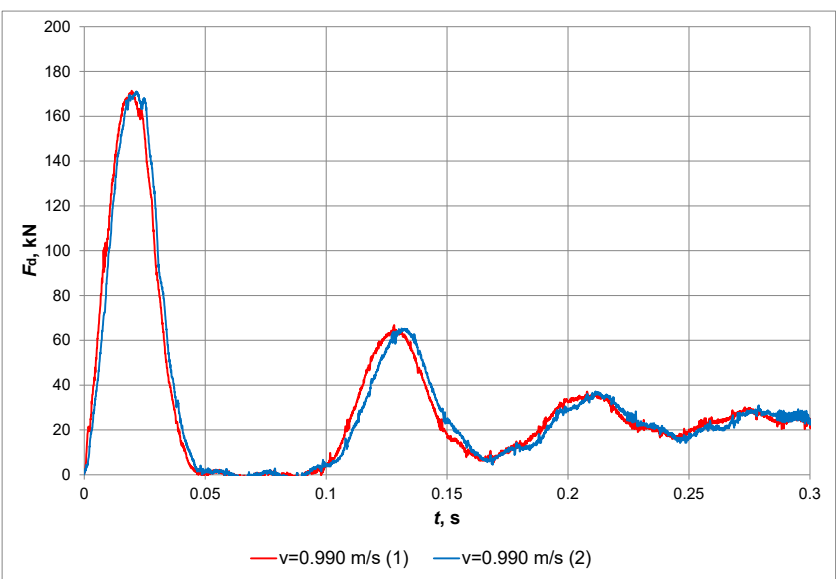

(b)

Figure 12: APP bolt rod load $F_{\mathrm{d}}$ curves as functions of time $t$ : (a) the rod was shorn; (b) the rod was not shorn.

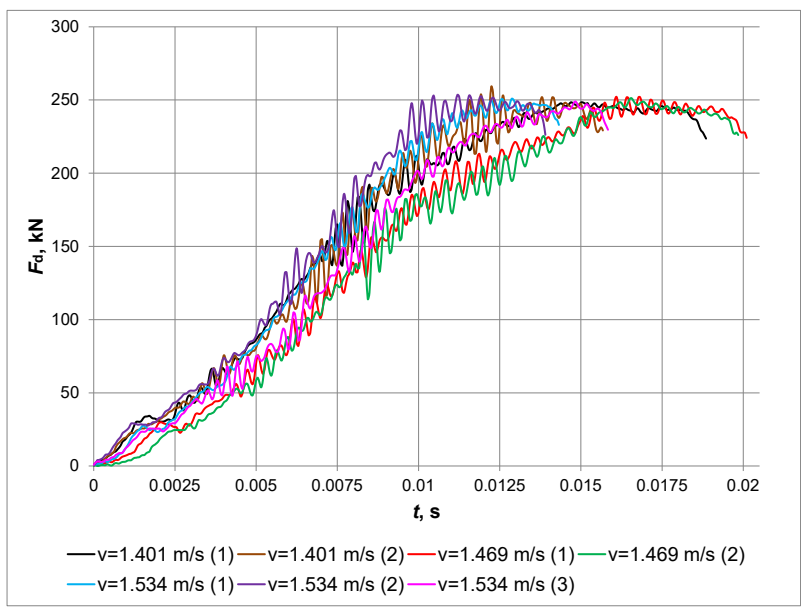

(a)

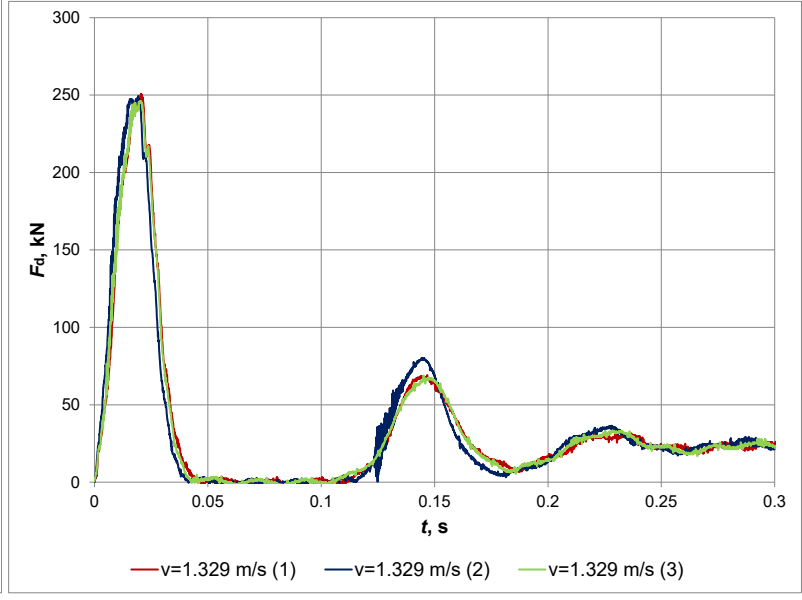

(b)

Figure 13: APB bolt rod load $F_{\mathrm{d}}$ curves as functions of time $t$ : (a) the rod was shorn; (b) the rod was not shorn. 
Table 6: Comparison of bolt rod mechanical properties under static and dynamic loading (part 1).

\begin{tabular}{|c|c|c|c|c|c|c|c|c|c|c|c|}
\hline $\begin{array}{l}\text { Bolt } \\
\text { type }\end{array}$ & $\begin{array}{l}\text { Grade of } \\
\text { steel }\end{array}$ & $\begin{array}{l}F_{\text {max }}, \\
\mathrm{kN}\end{array}$ & $\begin{array}{l}R_{\mathrm{m}}, \\
\mathrm{MPa}\end{array}$ & $F_{\text {smax }}, \mathrm{kN}$ & $t_{s}, M P a$ & $W_{s}, \mathrm{~kJ}$ & $t_{\mathrm{s}} / R_{\mathrm{m}}$ & $F_{\mathrm{dmax}}, \mathrm{kN}$ & $t_{\mathrm{d}}, \mathrm{MPa}$ & $W_{\mathrm{d}}, \mathrm{kJ}$ & $\mathrm{t}_{\mathrm{d}} / R_{\mathrm{m}}$ \\
\hline AM18 & A500S & $\begin{array}{l}175.5 \pm \\
4.1\end{array}$ & $\begin{array}{l}721.5 \pm \\
16.8\end{array}$ & $\begin{array}{l}131.9 \pm \\
4.7\end{array}$ & $\begin{array}{l}542.3 \pm \\
19.3\end{array}$ & $\begin{array}{l}0.775 \pm \\
0.061\end{array}$ & 0.752 & $\begin{array}{l}135.3 \pm \\
4.0\end{array}$ & $\begin{array}{l}556.0 \pm \\
16.6\end{array}$ & $\begin{array}{l}0.630 \pm \\
0.032\end{array}$ & 0.771 \\
\hline AM22 & A500sh & $\begin{array}{l}279.3 \pm \\
1.6\end{array}$ & $\begin{array}{l}762.3 \pm \\
4.3\end{array}$ & $\begin{array}{l}217.1 \pm \\
6.7\end{array}$ & $\begin{array}{l}592.5 \pm \\
18.4\end{array}$ & $\begin{array}{l}1.221 \pm \\
0.131\end{array}$ & 0.777 & $\begin{array}{l}225.5 \pm \\
7.0\end{array}$ & $\begin{array}{l}615.6 \pm \\
19.1\end{array}$ & $\begin{array}{l}1.203 \pm \\
0.064\end{array}$ & 0.808 \\
\hline APP & AP600V & $\begin{array}{l}207.7 \pm \\
0.9\end{array}$ & $\begin{array}{l}681.3 \pm \\
2.9\end{array}$ & $\begin{array}{l}165.2 \pm \\
2.7\end{array}$ & $\begin{array}{l}541.9 \pm \\
9.0\end{array}$ & $\begin{array}{l}0.971 \pm \\
0.036\end{array}$ & 0.795 & $\begin{array}{l}174.2 \pm \\
2.5\end{array}$ & $\begin{array}{l}571.6 \pm \\
8.3\end{array}$ & $\begin{array}{l}0.945 \pm \\
0.033\end{array}$ & 0.839 \\
\hline APB & AP770 & $\begin{array}{l}318.6 \pm \\
2.8\end{array}$ & $\begin{array}{l}830.4 \pm \\
7.3\end{array}$ & $\begin{array}{l}235.1 \pm \\
1.4\end{array}$ & $\begin{array}{l}612.8 \pm \\
3.7\end{array}$ & $\begin{array}{l}1.340 \pm \\
0.053\end{array}$ & 0.738 & $\begin{array}{l}250.8 \pm \\
1.9\end{array}$ & $\begin{array}{l}656.9 \pm \\
9.5\end{array}$ & $\begin{array}{l}1.269 \pm \\
0.062\end{array}$ & 0.791 \\
\hline
\end{tabular}

Table 7: Comparison of bolt rod mechanical properties under static and dynamic loading (part 2).

\begin{tabular}{llll}
\hline Bolt type & $F_{\text {dmax }} / F_{\text {smax }} \%$ & $t_{\mathrm{d}} / t_{\mathrm{s}}, \%$ & $E_{\mathrm{d}} / E_{\mathrm{s}}, \%$ \\
\hline AM18 & 102.6 & 102.5 & 81.3 \\
AM22 & 103.9 & 103.9 & 98.5 \\
APP & 105.4 & 105.5 & 97.3 \\
APB & 106.7 & 107.2 & 94.7 \\
\hline
\end{tabular}

the shearing of the bolt rod was $1.401 \mathrm{~m} / \mathrm{s}$. Example load $F_{\mathrm{d}}$ curves as functions of time $t$ during APB-type bolt rod tests at impact velocity $v=1.329 \mathrm{~m} / \mathrm{s}$ that did not result in the shearing of the bolt rod are presented in Fig. 13b.

\section{Results And Discussion}

\subsection{Comparison Of The Test Results}

The results of the single shear tests under impact loading demonstrated that the greatest shear work $W_{\mathrm{d}}$ was attained by APB-type bolt rods, followed by AM22, APP and AM18, respectively.

A comparison of the mechanical properties of bolt rods during shearing under static and dynamic loading as well as their reference to a static tensile test are presented in Tables 6 and 7.

Under static loading, the calculated maximum stress ratio values $t_{\mathrm{s}} / R_{\mathrm{m}}$ are within $0.738-0.795$, which is consistent with the test results presented in the literature and supported by numerous experiments conducted by Konowalski (2005). Based on multiple tests, the value $\mathrm{t}_{\mathrm{s}}=$ $(0.7-0.8) \cdot R_{\mathrm{m}}$ can be adopted for strength calculations for various grades of steel.

Under dynamic loading, the calculated maximum stress ratio values $t_{\mathrm{d}} / R_{\mathrm{m}}$ are within $0.771-0.839$, which is a result of the maximum dynamic load values $F_{\text {dmax }}$ measured during tests being greater by $2.6-6.7 \%$ than the maximum static load values $F_{\text {smax }}$. Similarly, the maximum stresses $t_{\mathrm{d}}$ under dynamic loading were greater than the maximum stresses $t_{\mathrm{s}}$ under static loading. Referring to many research studies, the phenomenon of simultaneously increasing steel strength and load rate is well known. Since the rate of deformation constitutes a very significant factor that influences the strength of metals, studies were conducted worldwide (Kinslov et al., 1970; Jurczak, 2007) in order to determine the characteristics of steel under dynamic loading. These studies indicate that yield stress $R_{\mathrm{e}}$ increases significantly under the dynamic loading of steel with $\approx 0.2 \%$ carbon (C) content. Experiments also indicate that the value of the force exerted under dynamic loading depends on the mass of the striking body as well as the impact velocity and the rate of the deformation of the sample.

Bolt rod tests under tensile impact loading with a maximum load rate of $v_{\max }=6 \mathrm{~m} / \mathrm{s}$ conducted to date at the Polish Central Mining Institute's test facility also confirm the increases in yield stress and steel strength compared to static tests. Furthermore, a significant difference between grades of steel can be found in the energy ratio $E_{\mathrm{d}} / E_{\mathrm{s}}$ (Table 7).

The $E_{\mathrm{d}} / E_{\mathrm{s}}[\%]$ value is clearly lower for the A500S steel intended for concrete reinforcement compared to the other grades, A500sh, AP600V and AP770, which are specifically intended for rock bolt rod production. Among the tested grades, the A500S steel is characterised by the lowest $\mathrm{A}_{5}$ value, which is $18 \%$.

Although the AM18 (A500S steel) and AM22 (A500sh steel) bolt rods are produced using similar technology that involves thermal hardening (with quenching), the A500S steel has lower content of carbon and other main alloying agents such as manganese $(\mathrm{Mn})$ and silicon ( $\mathrm{Si}$ ), which influence the increase in strength and yield stress. Similarly with APP (AP600V steel) and APB (AP770 steel) 

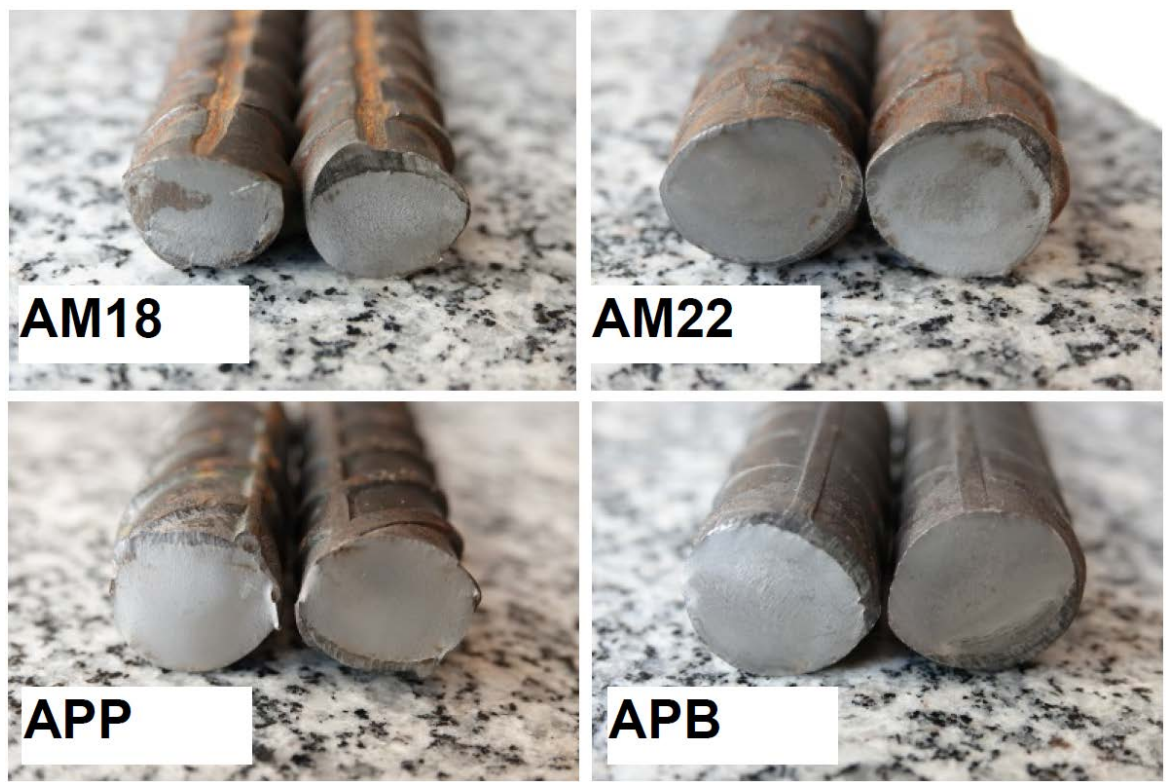

Figure 14: Samples view after single shear testing under impact loading.

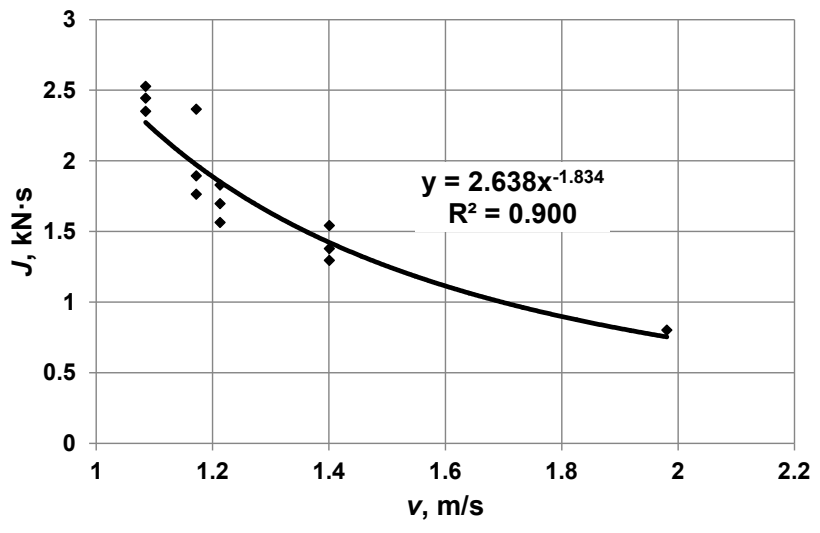

Figure 15: Chart of the relationship $J=f(v)$ obtained during APP bolt testing.

bolts, which are also produced using the same technology (continuous casting and slow cooling), differences can be found in their chemical compositions. Compared to the AP600V, the AP770 steel has a comparable content of carbon, chromium ( $\mathrm{Cr}$ ) and molybdenum (Mo), and a higher content of manganese, nickel (Ni), silicon and vanadium $(\mathrm{V}$ - also improves the impact strength of steel), which influence the increase in strength and yield stress. Austenite forming elements such as Mn, Ni and cobalt (Co) (which does not appear in the chemical compositions of the steel of the tested bolt rods) have a beneficial influence on the structure of steel even in minor amounts. The finegrained structure of primary austenite usually also serves to improve the mechanical properties and performance of steel. Increasing the concentration of an austenite forming element results in the occurrence of a semi-austenitic structure, consisting of a mixture of austenite and ferrite (Dobrzański, 1998). Fig. 14 presents example views of bolt rods after single shear testing under impact loading.

The $F_{\mathrm{d}}=\mathrm{f}(t)$ charts presented in Fig. 10b, 11b, 12b and 13b demonstrate tests that did not result in bolt rod shearing. Though the maximum load $F_{\mathrm{dmax}}$ was comparable with the one obtained during tests that did result in rod shearing, the impulse $J$ of the force and the energy of the ram were not sufficient to shear the rod.

Analysing the tests that resulted in bolt rod shearing confirmed that the impulse $J$ of the force decreases together with the increase in impact velocity $v$. An example can be found in the tests of APP-type bolts, whose load curves as functions of time are presented in Fig. 12. The relationship $J=\mathrm{f}(v)$ calculated on their basis is presented in Fig. 15. Despite the clearly decreasing tendency of the impulse $J$ of the force, the calculated work $W_{\mathrm{d}}$ values during bolt rod shearing under impact loading are very similar, whereas their average value and standard deviation are $W_{\mathrm{d}}=(0.945$ $\pm 0.033) \mathrm{kJ}$.

It is thus proposed that an additional assessment criterion of bolts intended for use under dynamic loading be adopted in the form of the shear work value $W_{\mathrm{d}}$. This particularly concerns bolts intended for use under the conditions of roof caving, tremors and rock bursts, which exert dynamic loads on the bolt rods. For example, before the bolts are installed in LKAB mines, their impact strength is checked during tensile tests at a test facility in 
the mine. Taking into account local geological and mining conditions, the mines themselves determine the minimum energy value that must be dissipated by the bolts under dynamic tensile loading without failure (usually, this value is within $19-30 \mathrm{~kJ}$ ). However, there are no studies concerning the value of the bolt shear work (the energy dissipated by the bolt rod until its shearing) under impact loading, which as can be seen in the conducted tests is considerably lower than the value of the energy dissipated by the bolts under tensile impact loading.

Due to the fact that most of the shear bolt rod tests' results published in research studies are performed on rods installed in rock or concrete blocks, it is impossible to directly compare them with the test results presented in this article. These differences are connected with the fact that in the area of the bolt rods' destruction installed in rock or concrete blocks, there is not only a shear zone, but also a zone of the rod tension and compression (Jalalifar et al., 2005). However, the static shear tests' results presented in this article are comparable and converge with the results of direct shear tests only of the bolt rod presented by Jalalifar (2006) in his $\mathrm{PhD}$ thesis. The results above apply to both the shape of the charts $F_{\mathrm{s}}=\mathrm{f}(L)$ and the value of the maximum load $F_{\text {smax }}$, and additionally, the deformation $L_{\mathrm{c}}\left(L_{\mathrm{c}}\right.$ - Displacement until the point of rod shearing). There is no commonly known research studies based on dynamic shear tests of the bolt rod made using the method presented in this article.

Thus far, when designing workings in Polish underground mines, the selection of bolts for the given geological and mining conditions was typically influenced by the value of the force and the stress occurring in the bolt rod. Analysis of recent accidents in workings with roof bolting in Polish copper mines indicates that greater attention needs to be paid to the energy dissipated by the bolts during tension and shearing under impact loading. Currently, copper mines are more focused on the impact strength value of the steel used to produce the bolt rods, which is a positive phenomenon serving to improve the work safety of the miners and the stability of the working support.

\subsection{Mathematical Model of The Bolt Rod Dynamic Shear Load in The Test Stand}

The characteristics $F_{\mathrm{d}}=\mathrm{f}(t)$ were determined to enable the use of the experimental test results for the modelling joint purposes of the bolt rod with the rock mass (Cała et al., 2001). These characteristics simulate the first peak of the load caused by the seismic wave (Fig. 1). Analysing the
$F_{\mathrm{d}}=\mathrm{f}(t)$ courses of all tests that resulted in rod shearing showed a similar character; therefore, it was attempted to formulate mathematical relationships for the bolt shearing force under impact loading as a function of time of the duration of the impulse of the force for each type of bolt. An 'extreme' function implemented in the ORIGIN software was adopted as an estimated function of the load shearing of the bolt rod.

The mathematical formula of this function is as follows:

$$
\begin{gathered}
y=y 0+A \cdot e^{\left(-e^{-z)}-z+1\right)} \\
z=\frac{(x-x c)}{w}
\end{gathered}
$$

where: $y 0$ - offset, $A$ - amplitude, $x c$ - impulse centre, $w$-impulse width.

Function estimations are performed based on the measurement data originating from specific tests, with assumed amplitude of $A>0$, impulse width of $w>0$ and offset of $y 0=0$.

Fig. 16 presents example courses of the $F_{\mathrm{d}}=\mathrm{f}(t)$ function as well as the estimated 'extreme' functions (per formulas 11 and 12) for the AM18 and AM22 bolts: with a load rate $v=1.085 \mathrm{~m} / \mathrm{s}$ for the AM18 bolt and with a load rate $v=1.401 \mathrm{~m} / \mathrm{s}$ for the AM22 bolt.

Fig. 17 presents example courses of the $F_{\mathrm{d}}=\mathrm{f}(t)$ function as well as the estimated 'extreme' functions (per formulas 11 and 12) for the APP and APB bolts: with a load rate $v=1.085 \mathrm{~m} / \mathrm{s}$ for the APP bolt and with a load rate $v=$ $1.401 \mathrm{~m} / \mathrm{s}$ for the APB bolt.

The courses of 'extreme' functions obtained via computer estimation indicate their correct selection for the registered measurement data, which is confirmed by the high coefficient of determination $R^{2}$ values. The values of amplitudes $A$ are also very similar to the $F_{\text {dmax }}$ values obtained during measurements conducted during the tests.

\section{Conclusions}

The developed method of single shear testing of bolt rods under impact loading allows to obtain repeatable test results concerning maximum bolt rod shearing force, shear stress and shear work values.

It is proposed that the shear work value $W_{\mathrm{d}}$ obtained during single shear tests should become an additional assessment parameter determining whether bolt rods are appropriate for utilisation under roof caving, tremor and rock burst conditions. This parameter can also be used 

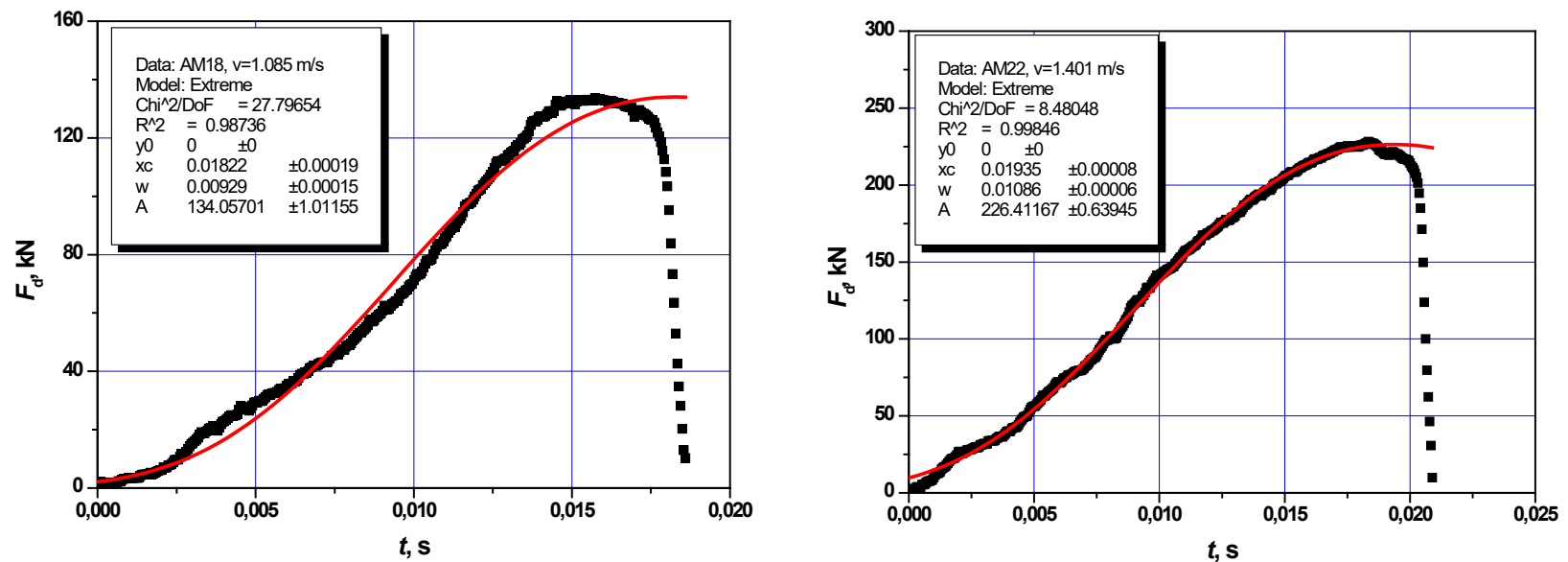

Figure 16: Estimated AM18 and AM22 bolt rod shearing functions during single shear testing under impact loading.
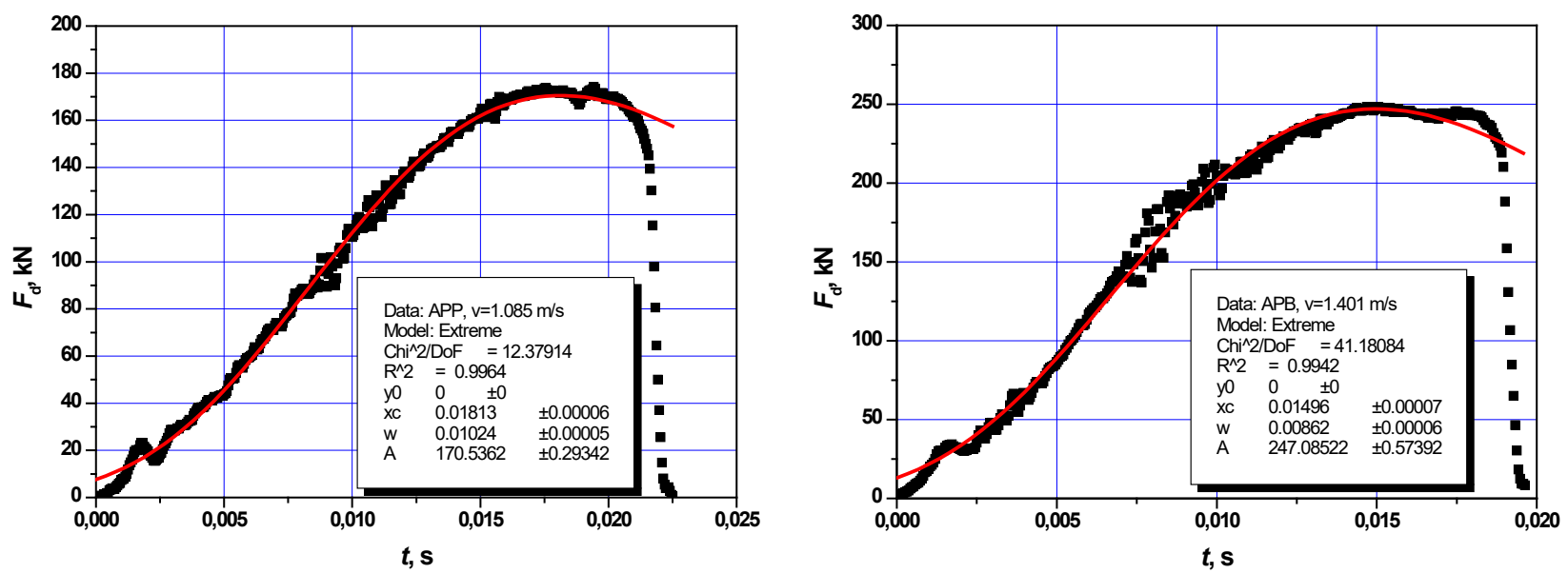

Figure 17: Estimated APP and APB bolt rod shearing functions during single shear testing under impact loading.

during rock bolt support design as well as for comparisons of various types of bolt rods, which is of significant importance to bolt manufacturers.

Comparative shear tests of four types of bolt rods under static and impact loading showed that APB-type bolt rods made of AP770 steel, which is characterised by the highest strength $\left(R_{\mathrm{m}}=830.4 \mathrm{MPa}\right.$ at $\left.A_{5}=19 \%\right)$, exhibited the greatest shear work $W_{\mathrm{s}}=1.340 \pm 0.053 \mathrm{~kJ}$ and $W_{\mathrm{d}}=1.269 \pm 0.062 \mathrm{~kJ}$. AM22-type bolt rods exhibited a very similar work value $\left(W_{\mathrm{s}}=1.221 \pm 0.131, W_{\mathrm{d}}=1.203 \pm 0.064\right.$ $\mathrm{kJ})$. Though the AM22-type bolt rods made of A500sh steel demonstrated lower strength $\left(R_{\mathrm{m}}=762.3 \mathrm{MPa}\right)$ than the APB-type bolt, as well as a smaller diameter and cross section; they dissipated the impact energy better thanks to their higher plasticity $\left(A_{5}=23 \%\right)$. This could indicate a method of optimisation for bolts in order to increase their dynamic strength.
The mathematical relationships determined in the form of 'extreme' functions describing the actual $F_{\mathrm{d}}=$ $\mathrm{f}(t)$ courses of single bolt shearing under impact loading could find application in the load assessment process of bolt rods utilised under roof caving, tremor and rock burst conditions.

Further single shear tests of various types of bolt rods under impact loading are planned in the future.

\section{References}

[1] ArcelorMittal Kryvyi Rih. (2016). PJSC Product Catalogue. https://ukraine.arcelormittal.com/images/pdf/product_ catalog_en.pdf. Accessed 01 December 2018

[2] ASTM D7401-08, Standard Test Methods for Laboratory Determination of Rock Anchor Capacities by Pull and Drop Tests 
(Withdrawn 2017), ASTM International, West Conshohocken, PA, 2008.

[3] ASTM F432-13, Standard Specification for Roof and Rock Bolts and Accessories, ASTM International, West Conshohocken, PA, 2013.

[4] Aziz N., Rink O., Rasekh H., Hawkins E., Mirzaghorbanali A., Yang G., Khaleghparast S., Mills K., Nemcik J. and Li X., (2017). Single shear testing of various cable bolts used in Australian mines, in Naj Aziz and Bob Kininmonth (eds.), Proceedings of the 17th Coal Operators' Conference, Mining Engineering, University of Wollongong, 8-10 February 2017, 222-230.

[5] Aziz N., Jalalifar H., Remennikov A., Sinclair S and Green A, (2008). Optimisation of the Bolt Profile Configuration for Load Transfer Enhancement, in Aziz, N (ed), Coal 2008: Coal Operators' Conference, University of Wollongong \& the Australasian Institute of Mining and Metallurgy, 2008, 125-131.

[6] Aziz, N, Pratt, D \& Williams, R, (2003). Double Shear Testing of Bolts, in Aziz, N (ed), Coal 2003: Coal Operators' Conference, University of Wollongong \& the Australasian Institute of Mining and Metallurgy, 2003, 154-161.

[7] Aziz N., Rasekh H., Mirzaghorbanali A., Yang G., Khaleghparast S., Nemcik J. (2018). An Experimental Study on the Shear Performance of Fully Encapsulated Cable Bolts in Single Shear Test. Rock Mechanics and Rock Engineering, Volume 51, Issue 7, 2207-2221.

[8] BS 7861-1:2007, Strata reinforcement support system components used in coal mines - Part 1: Specification for rockbolting. British Standards Institution.

[9] BS EN 1537:2000, Execution of special geotechnical work Ground anchors. British Standards Institution.

[10] BS EN 10204:2004, Metallic products. Types of inspection documents. British Standards Institution.

[11] Burtan Z., Chlebowski D., Cieślik J, Zorychta A. (2017). Analiza parametrów sejsmiczności indukowanej górotworu w rejonach eksploatacyjnych O/ZG Rudna. [The analysis of induced seismicity of the rock strata in the stope regions in the Rudna mine] Zeszyty Naukowe Instytutu Gospodarki Surowcami Mineralnymi i Energią Polskiej Akademii Nauk 97, 145-162 (in Polish).

[12] Cała M., Flisiak J., Tajduś A. (2001). Mechanizm wspótpracy kotwi z górotworem o zróżnicowanej budowie. [The interaction between a rock bolt and a rock mass with varied structure]. Biblioteka Szkoły Eksploatacji Podziemnej. Seria z Lampką Górniczą 8. Kraków (in Polish).

[13] Craig P., Aziz N. (2010) Shear testing of $28 \mathrm{~mm}$ hollow strand" TG" cable bolt, Coal Operators' Conference, University of Wollongong, Wollongong, 171-179.

[14] DIN 21521-1:1990-07, Gebirgsanker für den Bergbau und den Tunnelbau - Begriffe [German Standard: Rock bolts for mining and tunnelling; terms], Beuth Verlag $\mathrm{GmbH}$ (in German).

[15] DIN 21521-2:1993-02, Gebirgsanker für den Bergbau und den Tunnelbau - Allgemeine Anforderungen für Gebirgsanker aus Stahl - Prüfungen [German Standard: Rock bolts for mining and tunnel support; general specifications for steel-bolts; tests, testing methods], Beuth Verlag GmbH (in German).

[16] Dobrzański L.A. (1998). Metaloznawstwo z podstawami nauki o materiałach. [Metal science with the basics of materials science] Wydawnictwo Naukowo-Techniczne, Warszawa (in Polish).
[17] Dubiński J., Konopko W. (2000). Tąpania: ocena, prognoza, zwalczanie [Tremors: evaluation, forecast, elimination]. Główny Instytut Górnictwa, Katowice (in Polish).

[18] Dubiński J., Mutke G. (1996). Characteristics of mining tremors within the near-wave field zone. Pure and Applied Geophysics 147(2), 249-261.

[19] Drzewiecki, J. 2002. The collapse of the mining workings due to movements of rocks. Proceedings of the International Scientific-Technical Symposium 'Rockburst 2002'. The State of Research and Prevention. Central Mining Institute, Katowice, Poland [in Polish].

[20] Fuławka K., Mertuszka P., Pytel W. (2018) Monitoring of the stability of underground workings in Polish copper mines conditions, E3S Web Conf., Volume 29, No. 00008, 1-14.

[21] Gilbert D., Mirzaghorbanali A., Li X., Rasekh H., Aziz N., Nemcik J. (2015). Strength Properties of Fibre Glass Dowels Used for Strata Reinforcement in Coal Mines. In: 15th Coal Operators' Conference. The Australasian Institute of Mining and Metallurgy and Mine Managers Association of Australia, University of Wollongong, Wollongong, 365-375.

[22] Gogolewska A., Kaźmierczak M. (2014). Aktywność sejsmiczna w wybranych polach eksploatacyjnych w KGHM Polska Miedź S.A. O/ZG Rudna. [Seismic activity in chosen mining fields in KGHM Polska Miedź S.A. O/ZG Rudna copper ore mine] CUPRUM - Czasopismo Naukowo-Techniczne Górnictwa Rud 4(73), 35-54. (in Polish).

[23] Haile A.T., Le Bron K. (2001). Simulated rockburst experiment evaluation of rock bolt reinforcement performance. SAIMM The Journal of The South African Institute of Mining and Metallurgy 101(5), 247-252.

[24] Halliday D., Resnick R., Walker J. (2007). Podstawy Fizyki, Tom 1. [Fundamentals of Physics, Part 1] Wydawnictwo Naukowe PWN, Warszawa (in Polish).

[25] Jalalifar, H., Aziz, N. I. \& Hadi, M. N. (2005). Rock and bolt properties and load transfer mechanism in ground reinforcement. $20^{\text {th }}$ World Mining Congress 2005: Mining and Sustainable Development (pp. 629-635). Iran: Geological Survey of Iran.

[26] Jalalifar, Hossein, A new approach in determining the load transfer mechanism in fully grouted bolts, PhD thesis, School of Civil, Mining and Environmental Engineering, University of Wollongong, 2006. http://ro.uow.edu.au/theses/855.

[27] Jurczak W. (2007). Wpływ prędkości odksztatcenia na właściwości mechaniczne stopu AlZn5Mg2CrZr i stali kadtubowej kat. A. [Effect of shape of notch and strain rate on dynamic properties of AlZn5Mg2CrZr alloy] Zeszyty Naukowe Akademii Marynarki Wojennej 48(4), 37-47. (in Polish).

[28] Kidybiński A. (Edited by) (2009). Stateczność górotworu i obudowy przy łącznym obciążeniu statycznym i dynamicznym. [Rock mass and mining support stability under combined static and dynamic loads] Główny Instytut Górnictwa, Katowice (in Polish).

[29] Kinslov R. (Edited by) (1970). High-Velocity Impact Phenomena. Academic Press, New York, London.

[30] Konowalski K. (2005). Ćwiczenia laboratoryjne z wytrzymatości materiatów. Statyczna próba ścinania. [Laboratory exercises on material strength. Static shear test.] Politechnika Szczecińska, Katedra Mechaniki i Podstaw Konstrukcji Maszyn, Szczecin. (in Polish). 
[31] Labrie D., Doucet C., Plouffe M. (2008). Design guidelines for the dynamic behaviour of ground support tendons. Phase I and II. CANMET-MMSL, Ottawa.

[32] Li C.C., Stjern G., Myrvang A. (2014). A review on the performance of conventional and energy-absorbing rock bolts. Journal of Rock Mechanics and Geotechnical Engineering 6(4), 315-327.

[33] Li L., Hagan P.C., Saydam S., Hebblewhite B., Li Y. (2016). Parametric Study of Rock bolt Shear Behaviour by Double Shear Test. Rock Mechanics and Rock Engineering 49(12), 4787-4797.

[34] Li, X., Yang, G., Nemcik, J., Mirzaghorbanali, A. \& Aziz, N. (2019). Numerical investigation of the shear behaviour of a cable bolt in single shear test. Tunnelling and Underground Space Technology, Volume 84, February 2019, 227-236.

[35] Milev A.M., Spottiswoode S.M. (2005). Strong ground motion and site response in deep South African mines. SAIMM The Journal of The South African Institute of Mining and Metallurgy 105(7), 515-524.

[36] Milev A.M., Spottiswoode S.M., Rorke A.J., Finnie G.J. (2001) Seismic monitoring of a simulated rockburst on a wall of an underground tunnel. SAIMM The Journal of The South African Institute of Mining and Metallurgy 101(5), 253-260.

[37] Minova Arnall. (2018). Kotwie wklejane typu APP, APG, APB Product Catalogue. http://www.arnall.com.pl/kotwie-wklejanetypu-app-apg-apb. Accessed 01 December 2018.

[38] Mirzaghorbanali, A., Rasekh, H., Aziz, N., Yang, G., Khaleghparast, S., \& Nemcik, J.A. (2017). Shear strength properties of cable bolts using a new double shear instrument, experimental study, and numerical simulation. Tunnelling and Underground Space Technology, Volume 70, November 2017, 240-253.

[39] Mutke G. (2007). Charakterystyka drgań wywołanych wstrząsami górniczymi w odległościach bliskich źródła sejsmicznego w aspekcie oceny zagrożenia tapnięciem. [Characteristics of near-field ground motion resulting from mining tremors to assessing of rockbursts hazard] Prace naukowe Głównego Instytutu Górnictwa No 872, Katowice. (in Polish).

[40] Mutke G., Masny W., Prusek S. (2016). Peak particle velocity as an indicator of the dynamic load exerted on the support of underground workings. Acta Geodyn. Geomater., Vol. 13, No. 4 (184), 367-378.

[41] Niedbalski Z., Małkowski P., Majcherczyk T. (2013). Monitoring of stand-and-roof-bolting support: Design optimization. Acta Geodyn. Geomater., Vol. 10, No. 2 (170), 215-226.

[42] Nierobisz, A. (2004). Analiza wpływu obciążeń dynamicznych na zachowanie się kotwi. [Influence analysis of dynamic charges on anchor maintenance]. Prace Naukowe GIG. Górnictwo i Środowisko/Gtówny Instytut Górnictwa, (2), 79-105. (in Polish).

[43] Nierobisz A., Pytlik A., Nowak H. (2001). Charakterystyka pracy kotwi przy obciążeniach dynamicznych w świetle badań stanowiskowych. [Performance characteristic of bolts under dynamic loads in the light of stand testing]. In: Nowoczesne Technologie Górnicze 2000 - Kotwienie. [Modern Mining Technology 2001. Bolting] Wydział Górnictwa i Geologii, Politechnika Śląska, Gliwice, 307-322. (in Polish).

[44] Niezgodziński M.E., Niezgodziński T. (1996). Wzory, wykresy i tablice wytrzymatościowe. [Formulas, charts and strength tables. 7th edn.] Wydawnictwo Naukowo-Techniczne, Warszawa. (in Polish)

[45] Plouffe M., Anderson T., Judge K. (2008). Rock bolt testing under dynamic conditions at CANMET-MMSL. In: Stacey TR, Malan D (ed) The 6th International Symposium on Ground Support in Mining and Civil Engineering Construction. Cape Town, 581-596.

[46] PN-G-15091:1998, Kotwie górnicze. Wymagania [Polish Standard: Rock bolts. Requirements]. Polski Komitet Normalizacyjny, Warszawa (in Polish).

[47] PN-G-15092:1999, Kotwie górnicze. Badania [Polish Standard: Rock bolts. Testing]. Polski Komitet Normalizacyjny, Warszawa (in Polish).

[48] PN-H-93215:1982, Walcówka i pręty stalowe do zbrojenia betonu. (Wycofana w 2012) [Rolled steel and steel bars for concrete reinforcement. (Withdrawn 2012)]. Polski Komitet Normalizacyjny, Warszawa (in Polish).

[49] Pytlik, A., Prusek, S., \& Masny, W. (2016). A methodology for laboratory testing of rockbolts used in underground mines under dynamic loading conditions. Journal of the Southern African Institute of Mining and Metallurgy, 116(12), 1101-1110.

[50] Prusek S., Masny W., Lubosik Z., Pytlik A. (2016). Support performance in conditions of dynamic load. In: 24th World Mining Congress Proceedings. Unerground Mining. IBRAM, Rio de Janeiro, 427-439.

[51] Pytel, W. (2003). Rock mass - mine workings interaction model for Polish copper mine conditions. International Journal of Rock Mechanics and Mining Sciences, 40(4), 497-526.

[52] Pytel W.M., Mertuszka P.P., Jones T., Paprocki H. (2019). Numerical Simulations of Geomechanical State of Rock Mass Prior to Seismic Events Occurrence-Case Study from a Polish Copper Mine Aided by FEM 3D Approach. In: Widzyk-Capehart E., Hekmat A., Singhal R. (eds) Proceedings of the 27th International Symposium on Mine Planning and Equipment Selection - MPES 2018. Springer, Cham, 417-427.

[53] Pytlik A., (2015a). Graniczne wartości obciążenia dynamicznego powodujące niszczenie okładzin górniczych. [Limit values of dynamic load causing destruction of mining lining] Przegląd Górniczy 5, 78-84. (in Polish).

[54] Pytlik A. (2015b). Process characteristics of hydraulic legs equipped with safety valves at dynamic load caused by $a$ mining tremor. Archives of Mining Sciences 60(2), 595-612.

[55] Pytlik A. (2018). Tests on hydraulic props equipped with yield valves at dynamic load modelling a rock burst. Archives of Mining Sciences 63(2), 477-489.

[56] Pytlik A. (2019). Tests of steel arch and rock bolt support resistance to static and dynamic loading induced by suspended monorail transportation. Studia Geotechnica et Mechanica, 2019; 41(2); 81-92.

[57] Pytlik A., Prusek S., Masny W. (2016). Methodology for laboratory testing of rock bolts used in underground mines under dynamic loading conditions. SAIMM Journal of The Southern African Institute of Mining and Metallurgy 116(12), 1101-1110.

[58] Rasekh H., Aziz N., Mirzaghorbanali A., Nemcik J., Li X., Yang G., Khaleghparast S. (2017). Double shear testing of cable bolts with no concrete face contacts. Coal Operators' Conference, University of Wollongong, Wollongong 231-239. 
[59] SANS 1408:2019 (ED. 2.01), Mechanical components for tendon based rock support systems. The South African Bureau of Standards.

[60] SANS 920:2011 (ED. 2.03), Steel bars for concrete reinforcement. The South African Bureau of Standards.

[61] Sengani F. (2018). Trials of the Garford hybrid dynamic bolt reinforcement system at a deep level gold mine in South Africa. SAIMM The Journal of The Southern African Institute of Mining and Metallurgy 118(3), 289-296.

[62] Shirzadegan S., Nordlund E., Zhang P. (2016a). In-situ dynamic testing of rock support at LKAB Kiirunavaara mine. In: Nordlund E, Jones TH, Eitzenberger A (eds) Proceedings of the 8th International Symposium on Ground Support in Mining and Underground. Luleå University of Technology, Luleå, 1-12.

[63] Shirzadegan S., Nordlund E., Zhang P. (2016b). Large Scale Dynamic Testing of Rock Support System at Kiirunavaara Underground Mine. Rock Mechanics and Rock Engineering 49(7), 2773-2794.

[64] Skrzypkowski K., Korzeniowski W., Zagórski K., Dudek P. (2017). Application of Long Expansion Rock Bolt Support in the Underground Mines of Legnica-Głogów Copper District. Studia Geotechnica et Mechanica, Vol. 39, No. 3, 2017, 47-57.

[65] Sjöberg J., Dahnér C., Malmgren L., Perman F. (2011). Forensic analysis of a rock burst event at the Kiirunavaara Mine results and implications for the future. In: Sainsbury D, Hart R, Detournay C, Nelson M (ed) Continuum and Distinct Element Numerical Modeling in Geomechanics. Itasca International Inc., Minneapolis, 67-74.

[66] Yang G., Aziz N., Rasekh H., Khaleghparast S., Li X., Nemcik J. (2018). Profile of Sheared Cable Bolts Strand Wires. Coal Operators' Conference, University of Wollongong, Wollongong, February 2018, 343-352. 